\title{
Novel Fe-Mn binary oxide-biochar as an adsorbent for removing Cd(II) from aqueous solutions
}

Guangcai Yin ${ }^{\mathrm{a}}$, Xiaowang Song ${ }^{\mathrm{a}}$, Lin Tao ${ }^{\mathrm{a}}$, Binoy Sarkar ${ }^{\mathrm{b}}$, Ajit K Sarmah ${ }^{\mathrm{c}}$, Wenxiang Zhang ${ }^{\text {a }}$, Qintie Lin ${ }^{\mathrm{a}}$, Rongbo Xiao ${ }^{\mathrm{a}}$, Qianjun Liu ${ }^{\mathrm{a}}$, Hailong Wang ${ }^{\mathrm{d}, \mathrm{e}, *}$.

${ }^{a}$ School of Environmental Science and Engineering, Guangdong University of Technology, Guangzhou 510006, China

${ }^{b}$ Lancaster Environment Centre, Lancaster University, Lancaster, LA1 4YQ, UK

${ }^{c}$ Department of Civil and Environmental Engineering, The Faculty of Engineering, The University of Auckland, Private Bag 92010, Auckland 1142, New Zealand

${ }^{d}$ Key Laboratory of Soil Contamination Bioremediation of Zhejiang Province, Zhejiang A \&F University, Hangzhou 311300, China

${ }^{e}$ Biochar Engineering Technology Research Center of Guangdong Province, School of Environmental and Chemical Engineering, Foshan University, Foshan 528000, China

${ }^{*}$ Corresponding author.

E-mail address: hailong.wang@fosu.edu.cn (H. Wang). 


\section{Graphical abstract}

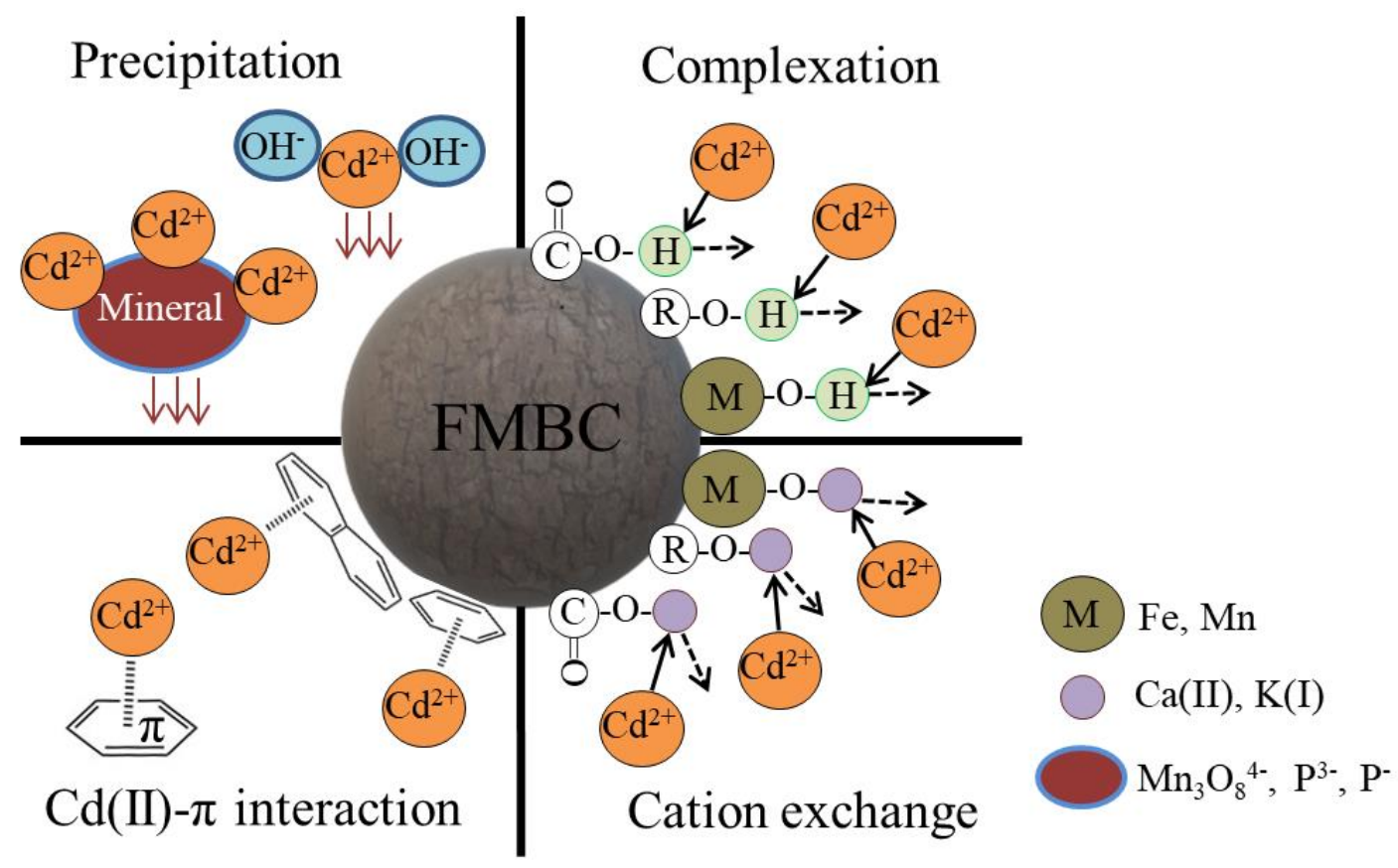

\section{Highlights}

- A novel Fe-Mn binary oxide-biochar (FMBC) was prepared.

- $\quad$ FMBC was effective for Cd(II) removal $(95.23 \mathrm{mg} / \mathrm{g})$ from aqueous phase .

- Dominant adsorption mechanism was Cd(II) precipitation with ferromanganese oxides. 
Abstract: In this study, a pristine biochar (BC) and Fe-Mn binary oxide-biochar (FMBC) were prepared using Pennisetum sp. straw as the feedstock for Cd(II) removal from aqueous solutions. Scanning electron microscopy (SEM) coupled with energy dispersive X-ray spectroscopy (EDX), X-ray photoelectron spectroscopy (XPS), X-ray diffraction (XRD), Fourier transform infrared (FTIR) spectroscopy and specific surface area (SSA) analyses revealed the physico-chemical characteristics of the pristine and designer adsorbents, suggesting that an ultrasonic treatment during synthesis enhanced the SSA and pore volume of the BC, and assisted successful loading of Fe-Mn binary oxide particles on the $\mathrm{BC}$ surface. The $\mathrm{Cd}(\mathrm{II})$ adsorption data of the adsorbents were fitted to the Langmuir isothermal and pseudo-second-order kinetic models. At a system temperature of $25^{\circ} \mathrm{C}$ and $\mathrm{pH} 5$, the maximum $\mathrm{Cd}(\mathrm{II})$ adsorption capacities of $\mathrm{BC}(30.58$ $\mathrm{mg} / \mathrm{g}$ ) and FMBC (95.23 mg/g) were obtained. Multiple Cd(II) adsorption mechanisms by FMBC were identified, including precipitation with minerals, complexation with surface functional groups, $\mathrm{Cd}(\mathrm{II})-\pi$ interactions, and cation exchange. As the most dominant adsorption mechanism, Cd-O bonds were formed on the FMBC surfaces precipitating $\mathrm{Cd}(\mathrm{OH})_{2}(63.9 \mathrm{wt} \%)$ and $\mathrm{CdO}(36.1 \mathrm{wt} \%)$. The FMBC thus could be potentially used as an effective adsorbent for $\mathrm{Cd}(\mathrm{II})$ removal from aqueous solutions.

Keywords: Water treatment; Adsorption mechanism; Heavy metal removal; Designer biochars. 


\section{Introduction}

Cadmium $(\mathrm{Cd})$ can enter into the aquatic ecosystem from both natural and anthropogenic sources and accumulate in the food chain, posing serious threats to aquatic organisms and human health $[1,2]$. Long-term exposure of $\mathrm{Cd}$ to humans can cause various types of disorders such as softening of bones, renal failure and neurological issues, and even can have a carcinogenic effect [3]. Therefore, it is necessary to find an efficient and environmentally friendly adsorbent for removing $\mathrm{Cd}$ from water which is one of the most important entry pathways for the heavy metal into the human body. To address this problem, numerous Cd-contaminated wastewater treatment techniques including chemical precipitation, membrane separation [4], ultrafiltration [5], electrolytic recovery [6], and ion exchange [7] have been investigated in the past. However, the application of these techniques is inherently limited because of high cost, sludge disposal, and secondary pollution problems [8].

In the past few years, increasing number of researchers have investigated biochar (a biomass-derived carbonaceous material) due to their high effectiveness, easy application and regeneration during contaminant removal processes $[9,10]$. Biochars have been reported as promising adsorbents for removing heavy metals from wastewater [11]. Particularly, biochars modified with oxidic composites have been reported as excellent adsorbents for heavy metal removal in aqueous solutions $[12,13]$, because biochars can form inner-sphere complexes with heavy metals through its metal oxide and O-containing functional groups, and also via cation exchange, and cation- $\pi$ bonding $[14,15]$. The maximum adsorption capacity of $\mathrm{Pb}(\mathrm{II}), \mathrm{Cu}(\mathrm{II})$, and $\mathrm{Cd}(\mathrm{II})$ by hickory wood biochar modified with $\mathrm{KMnO}_{4}$ could reach $153.1,34.2$, and $28.1 \mathrm{mg} / \mathrm{g}$, respectively, much higher than that of the pristine hickory wood biochar [16].Recently, Wu et al. (2019) revealed the dynamic interactions between amended biochar and soil 
oxide minerals which significantly affected the immobilization pathways of metals in contaminated soils [17].

In recent years, Fe-Mn binary oxide adsorbents, which are effective for removing heavy metals such as $\mathrm{Cd}(\mathrm{II}), \mathrm{Pb}(\mathrm{II}), \mathrm{Co}(\mathrm{II})$, and $\mathrm{As}(\mathrm{III})$, have attracted significant attention $[18,19]$. Fe-Mn binary oxides are the combination of iron oxyhydroxides and manganese dioxide, and they could enhance the adsorption capacity of anions due to their physico-chemical characteristics, such as increased specific surface area (SSA), undergoing concurrent redox reactions and oxyanion exchange phenomena [20]. Unfortunately, the weak mechanical strength of Fe-Mn binary oxide adsorbents is an issue for practical use mainly because of the release of $\mathrm{Mn}(\mathrm{II})$. Serious diseases, such as compulsive behaviors, emotional lability, hallucinations, and intellectual impairment in humans, can be caused by $\mathrm{Mn}(\mathrm{II})$ if present in the drinking water, which may limit the widespread application of Fe-Mn binary oxide adsorbents for water treatment $[21,22]$. Therefore, it is necessary to immobilize Fe-Mn binary oxides onto a host material to prevent the $\mathrm{Mn}(\mathrm{II})$ release during water treatment application so as to reduce the risk of secondary pollution [23]. Composites of Fe-Mn binary oxides with biochar could combine the advantages of both materials, and were reported previously as an excellent As(III) removing agent from contaminated water [254,25]. Only a few studies have focused on the potential role of Fe-Mn binary oxides-biochar composites as an adsorbent of $\mathrm{Cd}(\mathrm{II})$ in aqueous solutions, and the mechanism of $\mathrm{Cd}(\mathrm{II})$ adsorption on those composites is still unclear [26].

Therefore, the overarching purpose of this study is to develop a relatively simple and innovative adsorbent derived from biomass and combined with Fe-Mn binary oxides for the removal of $\mathrm{Cd}(\mathrm{II})$ from aqueous solutions. The specific objectives are: (1) to explore the physico-chemical characteristics of the novel Fe-Mn binary oxide- 
biochar (FMBC) adsorbent derived from Pennisetum sp. straw; (2) to determine the removal capacity of $\mathrm{Cd}(\mathrm{II})$ by $\mathrm{FMBC}$ and the pristine biochar (BC); and (3) to unravel the $\mathrm{Cd}(\mathrm{II})$ removal mechanisms by FMBC adsorbent. It is envisaged that the present study would facilitate: (i) cleaner production of biomass-derived biochar from straws, (ii) wastewater treatment using the designer biochar adsorbent, and (iii) mechanistic understanding of heavy metal removal from water using designer biochar adsorbents.

\section{Materials and methods}

\subsection{Materials}

The Pennisetum sp. straw, obtained from Guangzhou, Guangdong Province, China, was washed with deionized water, dried at $60^{\circ} \mathrm{C}$ temperature, milled into particles with a length of $2-3 \mathrm{~cm}$, and ground to pass through a 100-mesh sieve. The preparation of biochar was described previously [27]. In the present work, we adjusted the pyrolysis temperature at $600{ }^{\circ} \mathrm{C}$ to fabricate the $\mathrm{BC}$. Approximately $5 \mathrm{~g}$ of the $\mathrm{BC}$ was immersed in a mixture of $\mathrm{KMnO}_{4}(0.24 \mathrm{M}, 40 \mathrm{~mL})$ and $\mathrm{Fe}\left(\mathrm{NO}_{3}\right)_{3}(0.18 \mathrm{M}, 40 \mathrm{~mL})$ solutions, ultrasonically dispersed for $2 \mathrm{~h}$, dried in a water bath $\left(95^{\circ} \mathrm{C}\right)$, and finally pyrolyzed again at $600{ }^{\circ} \mathrm{C}$ for $0.5 \mathrm{~h}$ under $\mathrm{N}_{2}$ atmosphere to acquire the FMBC composite with an Fe:Mn:BC mass ratio of 1:4:25.

\subsection{Biochar characterization}

The elemental analyses of BC and FMBC were conducted on a Thermo flash 3000 element analyzer (EA-3000, Eurovector, Italy). The Fourier transform infrared (FTIR) spectra of both materials before and after Cd(II) adsorption were recorded within the wavelength range of $4000-400 \mathrm{~cm}^{-1}$ with dehydrated $\mathrm{KBr}$ as the sample pelleting matrix (iS50R, Thermo Fisher, USA). The SSA was determined by $\mathrm{N}_{2}$ adsorption isotherm at $77 \mathrm{~K}$ using a Micromeritics ASAP 2460 surface area analyzer (USA), and 
calculated by the Brunauer-Emmett-Teller (BET) method [28]. The pore size distribution was calculated by the Barrett-Joyner-Halender (BJH) method. The Fe and Mn bearing crystals on the biochar surfaces were identified using an X-ray diffraction (XRD) instrument (D8 ADVANCE, Bruker, Germany) equipped with a $\mathrm{CuK} \alpha$ radiation source, and scans were carried out between diffraction angles 2 to $80^{\circ}$ with cavity mounting. Elemental composition of the absorbent surfaces and valence states for Fe, $\mathrm{Cd}, \mathrm{Mn}, \mathrm{C}$ and $\mathrm{O}$ were analyzed by X-ray photoelectron spectroscopy (XPS) (Escalab $250 \mathrm{Xi}$, Thermo Fisher, USA) with a $2 \theta$ angular range spanning from 5 to $80^{\circ}$ with the spinning rate of $2 \mathrm{r} / \mathrm{s}$. An Al X-ray source was used with a $93.90 \mathrm{eV}$ passing energy between binding energy ranging from 0 to $1400 \mathrm{eV}$. The surface morphology and elemental distribution were analyzed using a scanning electron microscope (SEM) equipped with an energy dispersive X-ray spectroscopy (EDX) unit (S-3400N(II), Hitachi, Japan).

\subsection{Adsorption experiments}

The adsorption experiments were carried out in $50 \mathrm{~mL}$ polyethylene centrifuge tubes at $25{ }^{\circ} \mathrm{C}$. The $\mathrm{Cd}(\mathrm{II})$ solutions were prepared by dissolving its nitrate salt $\left(\mathrm{Cd}\left(\mathrm{NO}_{3}\right)_{2} \cdot 4 \mathrm{H}_{2} \mathrm{O}\right)$ in $0.01 \mathrm{~mol} / \mathrm{L} \mathrm{NaNO}_{3}$ as the background electrolyte. The initial concentrations of $\mathrm{Cd}(\mathrm{II})$ in the solutions were in the range of $50-200 \mathrm{mg} / \mathrm{L}$. For the batch studies, the adsorbents $(25 \mathrm{mg})$ and $\mathrm{Cd}(\mathrm{II})$ solution $(25 \mathrm{~mL})$ were added to the centrifuge tubes. The initial $\mathrm{pH}$ of the solution was adjusted to $5.0 \pm 0.05$ by adding 0.1 $\mathrm{mol} / \mathrm{L} \mathrm{NaOH}$ or $\mathrm{HNO}_{3}$ solutions. All the tubes were sealed and shaken at $200 \mathrm{rpm}$ in a water-bathing constant temperature vibrator for $24 \mathrm{~h}$ to reach the apparent equilibrium based on a preliminary study. For the adsorption kinetic studies, $25 \mathrm{mg}$ sample (BC or FMBC) was added to the $\mathrm{Cd}(\mathrm{II})$ solution $(25 \mathrm{~mL} ; 100 \mathrm{mg} / \mathrm{L})$. The suspension was sampled at different time intervals $(1,10,30,60,120,300,480,720$, and $1440 \mathrm{~min})$. 
The suspension was filtered immediately through a $0.45-\mu \mathrm{m}$ polyether sulfone filter membrane (PES, Syringe Filters, Germany) and subjected to $\mathrm{Cd}(\mathrm{II})$ analysis.

\subsection{Analysis methods}

Solution pH was measured using a PB-10 pH meter (Sartorius, Gottin-gen, Germany). The cation exchange capacity (CEC) was determined using the hexamminecobalt trichloride spectrophotometric method following the Environmental Protection Standards of People's Republic of China (HJ889-2017). The Cd(II) content in the solution was determined by atomic absorption spectroscopy (AAS, Z2000, Hitachi, Japan).

\section{Results and discussion}

\subsection{Characterization of $\mathrm{BC}$ and $\mathrm{FMBC}$}

\subsubsection{Specific surface area and pore volume}

The SSA, total pore volume and average pore size of the adsorbents are listed in Table 1. The SSA and pore volume of FMBC were $8.8030 \mathrm{~m}^{2} / \mathrm{g}$ and $0.0205 \mathrm{~cm}^{3} / \mathrm{g}$, respectively, about 4 times of the pristine $\mathrm{BC}\left(2.5137 \mathrm{~m}^{2} / \mathrm{g}\right.$ and $0.0058 \mathrm{~cm}^{3} / \mathrm{g}$, respectively). The increase in SSA and pore volume might be due to the fact that $\mathrm{KMnO}_{4}$ caused destruction of some nanopore structures of $\mathrm{BC}$ and transformed some of the nanopores into meso- or macropores because of the reagent's strong oxidative property [27]. The average pore sizes of BC and FMBC were 44.7 and $9.7 \mathrm{~nm}$, respectively. The Image J software was used to measure the Fe-Mn binary oxide particle sizes of FMBC (Fig. S1: Supplementary Materials), which suggested that the particle sizes varied from 0.10 to $0.50 \mu \mathrm{m}$. Compared with $\mathrm{BC}$, the increase of SSA and total pore volume as well as the decrease of average pore size were observed for FMBC, which indicated that Fe-Mn binary oxide particles were probably loaded on FMBC. 


\subsubsection{Surface morphology characteristics}

In order to investigate the morphological structures and surface elemental compositions of $\mathrm{BC}$ and FMBC, both adsorbents were observed by SEM-EDX. The SEM images (Fig. 1) showed that BC (Fig. 1a) had smaller porous structure and smoother surface than that of FMBC (Fig. 1b). The surface of FMBC was uniformly covered with small particles, as mentioned above (Fig. S1), and were thought to be composed of ferromanganese binary oxides. The EDX analysis indeed confirmed that Fe-Mn binary oxide particles were successfully loaded on the surface of the biochar (Fig. S2). The FMBC clearly exhibited greater atomic percentages of Mn (1.27\%), Fe $(0.93 \%)$ and $\mathrm{O}(18.08 \%)$ than $\mathrm{BC}(\mathrm{Mn}=0.04 \%, \mathrm{Fe}=0.03 \%$ and $\mathrm{O}=5.24 \%)($ Fig. S2 $)$. According to Table S1 (Supplementary Materials), the Fe and Mn contents decreased while $\mathrm{Cd}$ content increased after the adsorption experiment, which suggested that $\mathrm{Fe}$ and Mn had big devotion to the adsorption of $\mathrm{Cd}(\mathrm{II})$ on FMBC. The increase of $\mathrm{Cd}$ on the surface of FMBC could be attributed to the cation exchange between $\mathrm{Cd}(\mathrm{II})$ and metal ions $(\mathrm{Ca}(\mathrm{II}), \mathrm{K}(\mathrm{I}))$ associated with the surface functional groups of the biochar $[29,30]$.

The elemental analysis also showed that total carbon $(\mathrm{C})$, nitrogen $(\mathrm{N})$, and hydrogen $(\mathrm{H})$ contents of $\mathrm{BC}$ and $\mathrm{FMBC}$ were $73.79,0.86,2.93 \%$, and 46.96, 0.91, $2.43 \%$, respectively (Table 1). The reduction of $\mathrm{C}$ and $\mathrm{H}$ contents in FMBC after the addition of Fe-Mn binary oxide particles might be due to the strong oxidizing effect of $\mathrm{KMnO}_{4}$ on the feedstock. On the other hand, Fe-Mn binary oxide particles on the surface of FMBC might also reduce the proportion of other elements, which was similar to the results of previous studies on various biochar-based composites $[31,32]$. The increase of $\mathrm{N}$ might be due to the introduction of $\mathrm{N}$ by $\mathrm{Fe}\left(\mathrm{NO}_{3}\right)_{3}$ during the modification process. 


\subsection{Cd(II) adsorption performance of BC and FMBC}

\subsubsection{Adsorption isotherms}

To evaluate the effect of initial Cd(II) concentrations $(50-200 \mathrm{mg} / \mathrm{L})$ on $\mathrm{Cd}(\mathrm{II})$ adsorption, the Langmuir and Freundlich models were used to describe the adsorption process (Fig. 2). The isotherm parameters obtained from these two models are summarized in Table 2. The Langmuir and Freundlich models are described by Eq. (1) and Eq.(2), respectively.

$\mathrm{C}_{\mathrm{e}} / \mathrm{Q}_{\mathrm{e}}=1 /\left(\mathrm{Q}_{\mathrm{m}} \times \mathrm{K}_{\mathrm{L}}\right)+\mathrm{C}_{\mathrm{e}} / \mathrm{Q}_{\mathrm{m}}$

$\ln \mathrm{Q}_{\mathrm{e}}=\ln \mathrm{K}_{\mathrm{F}}+\ln \mathrm{C}_{\mathrm{e}} / \mathrm{n}$

where, $\mathrm{Q}_{\mathrm{e}}(\mathrm{mg} / \mathrm{g})$ is equilibrium adsorbent-phase concentration, $\mathrm{Q}_{\mathrm{m}}(\mathrm{mg} / \mathrm{g})$ is maximum monolayer adsorption capacity. $\mathrm{K}_{\mathrm{L}}(\mathrm{L} / \mathrm{mg})$ is the Langmuir constant related to the affinity between an adsorbent and adsorbate, $\mathrm{K}_{\mathrm{F}}\left((\mathrm{mg} / \mathrm{g})(\mathrm{L} / \mathrm{mg})^{1 / \mathrm{n}}\right)$ is the Freundlich constant that represents the adsorption capacity of the adsorbent, $\mathrm{C}_{\mathrm{e}}(\mathrm{mg} / \mathrm{L})$ is the equilibrium aqueous-phase adsorbate concentration, and 1/n represents the adsorption intensity and determines the degree of non-linearity of the adsorption isotherm curve.

The Langmuir constant $\left(\mathrm{K}_{\mathrm{L}}\right)$ describes the adsorption energy, which was 3.5 and $0.0234 \mathrm{~L} / \mathrm{mg}$ for $\mathrm{FMBC}$ and $\mathrm{BC}$, respectively. The adjusted regression coefficients $\left(\mathrm{R}^{2}{ }_{\text {adj }}\right)$ of the Langmuir and Freundlich isotherm models were 0.9965 and 0.8970 , respectively, for FMBC. The Langmuir model was better fitted than that of the Freundlich model with a higher $\mathrm{R}^{2}$ adj value and relatively lower root mean squared error (RMSE) value (Table 2). Thus, the adsorption process of FMBC could be explained through a monolayer adsorption mechanism. The Langmuir model was the best fit to $\mathrm{Cd}(\mathrm{II})$ adsorption isotherm data, suggesting the existence of homogeneous active sites for Cd(II) on FMBC surfaces [33]. The maximum Cd(II) adsorption capacity of FMBC 
$(95.23 \mathrm{mg} / \mathrm{g})$ was approximately 3 times higher than that of $\mathrm{BC}(30.58 \mathrm{mg} / \mathrm{g})$. The difference in adsorption capacities between $\mathrm{BC}$ and FMBC might be attributed to variable adsorbent characteristics (e.g., pH, CEC, SSA and/or functional groups) (Table 1), and the variation in metal adsorption mechanisms as well [34]. The SSA of FMBC $\left(8.80 \mathrm{~m}^{2} / \mathrm{g}\right)$ was about 3.5 times of $\mathrm{BC}$, which resulted in a larger total pore volume in the surface of FMBC than $\mathrm{BC}$, and thus increased the active adsorption sites on FMBC. The CEC value of FMBC was two-fold higher than $\mathrm{BC}$, which again increased the amount of active sites to absorb the metal cation. These partly explained why FMBC had much larger adsorption capacity than BC. Moreover, the adsorption capacity of FMBC was larger than most of the previously reported adsorbents such as $\mathrm{MnO}_{2}$ modified biochar $(62.83 \mathrm{mg} / \mathrm{g})$, peanut husk biochar $(28.99 \mathrm{mg} / \mathrm{g})$, municipal sewage sludge biochar (>40 mg/g), and Hikory biochar modified by $\mathrm{KMnO}_{4}(28.10 \mathrm{mg} / \mathrm{g})$ [35].

A dimensionless constant, called separation factor (RL) (Eq. 3), was used to indicate whether the adsorption process was favorable or not [25].

$\mathrm{R}_{\mathrm{L}}=1 /\left(1+\mathrm{K}_{\mathrm{L}}\right) \mathrm{C}_{0}$

In this study, $\mathrm{R}_{\mathrm{L}}$ values of $\mathrm{BC}(0.0049-0.0195)$ and FMBC $(0.0011-0.0044)$ were between 0 and 1; therefore, the adsorption process was favorable. In addition, the $\mathrm{R}_{\mathrm{L}}$ values of FMBC were lower than that of BC, implying a higher affinity between $\mathrm{Cd}(\mathrm{II})$ and $\mathrm{FMBC}$ than $\mathrm{Cd}(\mathrm{II})$ and $\mathrm{BC}$.

The Freundlich constant $\left(\mathrm{K}_{\mathrm{F}}\right)$ represents the adsorption capacity of the adsorbent. The Freundlich model parameter $1 / \mathrm{n}$ is another indicator for predicting the thermodynamic favorability of an adsorption system. The adsorption of an absorbate occurs mainly via chemisorption when $1 / \mathrm{n}<1$. The values of $K_{\mathrm{F}}$ and $1 / \mathrm{n}$ were 62.33 $(\mathrm{mg} / \mathrm{g})(\mathrm{L} / \mathrm{mg})^{1 / \mathrm{n}}$ and 0.1095 , respectively, for FMBC, and $3.4736(\mathrm{mg} / \mathrm{g})(\mathrm{L} / \mathrm{mg})^{1 / \mathrm{n}}$ 
and 0.3913 for, respectively, for BC. In the present study, the 1/n value for FMBC and $\mathrm{BC}$ falling within the range of 0 to 1 indicated that chemisorption predominated in the adsorption process of Cd(II) onto FMBC and BC (Table 2) [36].

\subsubsection{Adsorption kinetics}

The Cd(II) adsorption by $\mathrm{BC}$ and FMBC was described by the pseudo-first-order (PFO) (Eq. (4)) and pseudo-second-order (PSO) kinetic models (Eq. (5)):

$\ln \left(\mathrm{Q}_{\mathrm{e}}-\mathrm{Q}_{\mathrm{t}}\right)=\ln \mathrm{Q}_{\mathrm{e}}-\mathrm{K}_{1} \mathrm{t}$

$\mathrm{t} / \mathrm{Q}_{\mathrm{t}}=1 /\left(\mathrm{K}_{2} \mathrm{Q}_{\mathrm{e}}{ }^{2}\right)+\mathrm{t} / \mathrm{Q}_{\mathrm{e}}$

where, $\mathrm{t}$ is the adsorption time, $\mathrm{Q}_{\mathrm{e}}(\mathrm{mg} / \mathrm{g})$ is the equilibrium adsorption capacity, and $\mathrm{Q}_{\mathrm{t}}$ ( $\mathrm{mg} / \mathrm{g})$ is the adsorption capacity at time $\mathrm{t}$, and $\mathrm{K}_{1}(1 / \mathrm{min})$ and $\mathrm{K}_{2}(\mathrm{~g} /(\mathrm{mg} \cdot \mathrm{min}))$ are adsorption rate constants for PFO and PSO models, respectively.

The PFO and PSO models are used to evaluate the kinetic mechanism of the whole adsorption process [37]. The kinetic model parameters in this study are summarized in Table 3. For FMBC, the adjusted regression coefficient $\left(\mathrm{R}^{2}{ }_{\text {adj }}\right)$ of the PSO model was 0.9999, indicating that a chemical adsorption process (ion exchange and chelation) dominated in the system [38]. Interestingly, the PSO model suggested that the adsorption rate $\left(\mathrm{K}_{2}\right)$ of $\mathrm{BC}(0.0325 \mathrm{~g} /(\mathrm{mg} \cdot \mathrm{min}))$ was slightly higher than that of FMBC $(0.0085 \mathrm{~g} /(\mathrm{mg} \cdot \mathrm{min}))$. This might be caused by the slower dispersibility of FMBC particles than $\mathrm{BC}$ particles in the suspension, leading to a relatively lower instant adsorption rate for FMBC than $\mathrm{BC}$, and more time would be needed for FMBC than $\mathrm{BC}$ for the same amount of $\mathrm{Cd}(\mathrm{II})$ adsorption under similar experimental conditions [39]. The overall Cd(II) adsorption ability of FMBC was much higher than that of BC, indicating that the FMBC surfaces were more easily accessible for binding $\mathrm{Cd}(\mathrm{II})$ in 
the aqueous solution than $\mathrm{BC}$ surfaces. It might be resulted by different characteristics of both materials, such as metal oxide contents, functional groups, micropores, charged surfaces, and biochar mineral phases [32].

As illustrated in Fig. 3a, the adsorption process of $\mathrm{Cd}(\mathrm{II})$ on $\mathrm{BC}$ and FMBC could be divided into two stages: a rapid initial adsorption during the first 50 min followed by a much slower phase until an adsorption equilibrium was reached after approximately $200 \mathrm{~min}$. The solution diffusion of adsorbents and exterior surface adsorption on adsorbents were the major driving forces for the rapid adsorption stage, and the internal diffusion was the slow adsorption stage [40]. Moreover, a two-step intra-particle diffusion model was also used in this study to give insights into the mechanism and determine the rate-limiting phases during the $\mathrm{Cd}(\mathrm{II})$ adsorption process. Here, the adsorbate uptake rate is proportional to the half power of time, as Eq. (6):

$Q_{t}=K_{i d} * t^{0.5}+I$

where, $\mathrm{Q}_{\mathrm{t}}(\mathrm{mg} / \mathrm{g})$ is the amount of adsorbate per unit mass of adsorbent at time $\mathrm{t}(\mathrm{min})$, $\mathrm{K}_{\mathrm{id}}\left(\mathrm{mg} / \mathrm{g} / \mathrm{min}^{1 / 2}\right)$ is the intra-particle diffusion constant, and $\mathrm{I}(\mathrm{mg} / \mathrm{g})$ is a constant associated with the thickness of the boundary layer, where a higher value of I corresponds to a greater effect on the limiting boundary layer.

It could be observed from Fig. $3 b$ that the curve edges were divided into two linear periods. The rate constants are listed in Table 4. The adsorption rates exhibited the order of $\mathrm{k}_{\mathrm{i}, 1}>\mathrm{k}_{\mathrm{i}, 2}$ for $\mathrm{Cd}(\mathrm{II})$ adsorption onto $\mathrm{BC}$ and $\mathrm{FMBC}$, which was consistent with previous studies $[35,41]$. The rapid adsorption stage might be attributed to the fast $\mathrm{Cd}(\mathrm{II})$ invasion into easily accessible outward surface adsorption sites on $\mathrm{BC}$ and FMBC, probably through physical adsorption, e.g., electrostatic attraction[42,43]. During the slow adsorption stage, the diffusion rate $\left(\mathrm{k}_{\mathrm{i}, 2}\right)$ declined, and the adsorption approached 
a saturation state. As the abundant $\mathrm{Cd}(\mathrm{II})$ were adsorbed on the exterior surfaces, fewer active sites were available for further adsorption, and then the adsorbed $\mathrm{Cd}(\mathrm{II})$ further entered into the microporous interior of FMBC and $\mathrm{BC}$, leading to an increased diffusion resistance [44]. This stage might involve diffusion of the adsorbate molecules from the exterior of the adsorbent into the pores of the adsorbent, along pore-wall surfaces, or both [45].

\subsubsection{Effect of initial $\mathrm{pH}$ on adsorption performance}

Generally, $\mathrm{pH}$ values can promote/hinder electrostatic interaction between an adsorbent and adsorbate by adjusting the surface charge density of the adsorbent or by influencing metal speciation and precipitation in the aqueous solution [46]. The $\mathrm{Cd}$ speciation diagram with $\mathrm{pH}$ values ranging from 1 to 12 are shown in Fig. S3. During the strong ionic species stage $(\mathrm{pH}<9)$, Cd species predominantly exist as $\mathrm{Cd}(\mathrm{II})$, which appears to be little affected by the $\mathrm{pH}$ variation. The $\mathrm{pH}$ impact on $\mathrm{Cd}(\mathrm{II})$ adsorption onto $\mathrm{BC}$ and $\mathrm{FMBC}$ was further evaluated by adjusting the initial $\mathrm{pH}$ of the solution to the values of 2, 3, 4, 5, 6, 7, 8, and 9 (Fig. 4). The adsorption process was highly dependent on $\mathrm{pH}$ as the removal efficiency increased continuously with an increase of the initial $\mathrm{pH}$. The $\mathrm{Cd}(\mathrm{II})$ removal increased sharply when $\mathrm{pH}$ value increased from 2 to 4 for $\mathrm{BC}$ and $\mathrm{FMBC}$, because the low $\mathrm{pH}$ conditions were more favorable for protonation on the surface of $\mathrm{BC}$ and $\mathrm{FMBC}$, and hence elevated the positively charged sites, strengthened the electrostatic repulsive-force between BC or FMBC surfaces and $\mathrm{Cd}(\mathrm{II})$, reducing $\mathrm{Cd}$ adsorption at the low $\mathrm{pH}$ range [47]. In addition, $\mathrm{MnO}_{\mathrm{x}}$ and $\mathrm{FeO}_{\mathrm{x}}$ supported on FMBC could dissolve into the solution as free ions at low $\mathrm{pH}$, thereby losing possible adsorption capacity for $\mathrm{Cd}(\mathrm{II})$ [39]. The positive charges of $\mathrm{H}(\mathrm{I})$ and $\mathrm{Cd}(\mathrm{II})$ were competitively trapped on the micelle surface at low $\mathrm{pH}$ conditions. With the increase of $\mathrm{pH}(\mathrm{pH}<\mathrm{pH}$ PZC $)$, the positive charge on the surface of $\mathrm{BC}$ and FMBC 
gradually diminished. At this time, the repulsive force between $\mathrm{BC}$ or FMBC and $\mathrm{Cd}(\mathrm{II})$ gradually decreased, so the adsorption capacity increased. With the elevation of $\mathrm{pH}(\mathrm{pH}$ $>\mathrm{pH}_{\mathrm{PZC}}$ ), the surface electrical properties changed from positive to negative, and the repulsive force became attraction force, which was favorable for adsorption. Furthermore, $\mathrm{Cd}(\mathrm{II})$ removal rates showed no apparent changes when $\mathrm{pH}$ ranged from 4 and 9 for FMBC, which could be attributed to the deprotonation of hydroxyl and carboxyl groups reaching their saturated adsorption [35], indicating acidic aqueous condition was not required during $\mathrm{Cd}(\mathrm{II})$ adsorption process on $\mathrm{BC}$ and $\mathrm{FMBC}$.

\subsection{Cd(II) Adsorption mechanisms on BC and FMBC}

\subsubsection{FTIR analysis}

FTIR spectra of FMBC and BC surface functional groups before and after $\mathrm{Cd}(\mathrm{II})$ adsorption are illustrated in Fig. 5. The bands at 3446 and $1564 \mathrm{~cm}^{-1}$ were assigned to -OH stretching vibration of alcohol/phenol and $-\mathrm{COOH}$ stretching of carboxylic acid, respectively, whereas bands at $1122 \mathrm{~cm}^{-1}$ were generated by $\mathrm{C}-\mathrm{O}$ stretching vibrations being in ether and carboxyl groups $[48,49]$. The bands at 582 and $626 \mathrm{~cm}^{-1}$ were likely due to the presence of $\mathrm{O}-\mathrm{Fe}\left(\mathrm{Fe}_{3} \mathrm{O}_{4}\right)$ and $\mathrm{O}-\mathrm{Mn}$ groups, respectively $[26,50]$, and the presence of the ferromanganese oxides was also confirmed by XRD (Fig. S4) and SEMEDX investigations (Fig. S2). The intense band at $1385 \mathrm{~cm}^{-1}$ was produced by symmetrical stretching vibration of carboxyl $\mathrm{C}=\mathrm{O}$ groups [39]. The band intensity also showed that FMBC had stronger carboxyl functional groups than $\mathrm{BC}$, which was conducive to $\mathrm{Cd}(\mathrm{II})$ adsorption, and thus the $\mathrm{Cd}(\mathrm{II})$ adsorption capacity of FMBC was much higher than that of $\mathrm{BC}$. However, the $\mathrm{Cd}(\mathrm{II})$ adsorption weakened these bands to a large extent, revealing that hydroxyl groups contributed to strong mono- or multidentate inner-sphere complexes (e.g., COO-Cd) and (Mn-O-Cd) during the 
adsorption of $\mathrm{Cd}(\mathrm{II})$ [51]. The hydroxyl groups of FMBC associated with both Fe and Mn participated in $\mathrm{Cd}(\mathrm{II})$ adsorption. In comparison with FMBC before and after adsorbing $\mathrm{Cd}(\mathrm{II})$, the $\mathrm{Mn}-\mathrm{O}$ band at $626 \mathrm{~cm}^{-1}$ almost disappeared, which might be related to $\mathrm{Cd}(\mathrm{II})$ precipitation with $\mathrm{MnO}_{\mathrm{x}}$. This implied that $\mathrm{MnO}_{\mathrm{x}}$ also played a critical role in $\mathrm{Cd}(\mathrm{II})$ adsorption performance of $\mathrm{FMBC}$.

\subsubsection{XRD analysis}

To further explore the plausible $\mathrm{Cd}$ precipitation mechanism, $\mathrm{FMBC}$ and $\mathrm{Cd}(\mathrm{II})-$ loaded FMBC samples were comparatively analyzed with XRD. Several new reflections appeared in $\mathrm{Cd}(\mathrm{II})$-loaded FMBC samples, which were associated with $\mathrm{Cd}_{2} \mathrm{Mn}_{3} \mathrm{O}_{8}, \mathrm{Cd}_{3} \mathrm{P}_{2}, \mathrm{CdP}_{2}$ and $\mathrm{Cd}(\mathrm{OH})_{2}$, respectively (Fig. S4), and this finding agreed with the results of Wang et al. (2018) [52]. The above precipitates formed in Cd(II)loaded biochar might be attributed to the precipitation reactions occurring between $\mathrm{Cd}(\mathrm{II})$ and the dissolved anions (e.g., phosphate) releasing from minerals in the biochar [53].

\subsubsection{XPS analysis}

XPS was used to characterize the chemical composition and electronic structure of elements in FMBC before and after Cd(II) adsorption. The XPS spectra of C 1s, O $1 \mathrm{~s}, \mathrm{Fe} 2 \mathrm{p}, \mathrm{Mn} 2 \mathrm{p}$ and $\mathrm{Cd} 3 \mathrm{~d}$ are shown in Fig. 6. Compared with BC, the surface C content of FMBC decreased (Fig. S5), which was confirmed by the elemental composition analysis using EDX (Fig. S2). The O content of FMBC, however, increased greatly after the modification because the $\mathrm{KMnO}_{4}$ treatment introduced $\mathrm{MnO}_{\mathrm{x}}$ particles and/or additional oxygen containing groups on the surface of FMBC [54]. As displayed in Fig. 6a, the C 1s peaks were at 284.75, 285.81, 286.75 and 289.08 $\mathrm{eV}$, which represented the $\mathrm{C}-\mathrm{C} / \mathrm{C}=\mathrm{C}, \mathrm{C}-\mathrm{O}-\mathrm{C} / \mathrm{C}-\mathrm{OH}, \mathrm{C}=\mathrm{O}$ and $-\mathrm{COOH}$ groups, 
respectively [55]. The $\mathrm{O} 1 \mathrm{~s}$ spectrum (Fig. 6b-c) could be divided into four peaks (529.2, $530.4,531.5$, and $532.5 \mathrm{eV})$, due to the existence of metal oxide (M-O), hydroxyl bonded to metal (M-OH), hydroxyl on FMBC surface $(\mathrm{C}-\mathrm{OH})$, and adsorbed $\mathrm{H}_{2} \mathrm{O}$ in the adsorbent, respectively [56]. Moreover, the area ratios of $\mathrm{C}-\mathrm{OH}$ decreased from 26.01 to $12.87 \%$ after $\mathrm{Cd}(\mathrm{II})$ adsorption by FMBC. However, the area ratio of $\mathrm{M}-\mathrm{OH}$ and M-O increased after Cd(II) adsorption (M-OH 39.16-40.37\%; M-O 21.82-23.00\%), on account of the formation of Mn-O-R ( $\mathrm{R}$ : functional groups), or Cd-O groups on the FMBC surface after Cd(II) adsorption. The reduction of oxygen in $\mathrm{C}-\mathrm{OH}$ suggested that hydroxyl groups existing in FMBC had participated in the adsorption process. As shown in Fig. 6d, a high resolution XPS scan of the Mn 2p of FMBC displayed double peaks at the binding energy values of 641.0 and $652.6 \mathrm{eV}$. The separation between $\mathrm{Mn}$ $2 \mathrm{p}_{3 / 2}$ and $\mathrm{Mn} 2 \mathrm{p}_{1 / 2}$ of $11.6 \mathrm{eV}$ indicated that $\mathrm{Mn}(\mathrm{IV})$ was the predominant Mn oxidation state in FMBC. There was no satellite peak between the peaks of Mn 2p $\mathrm{p}_{1 / 2}(653.8 \mathrm{eV})$ and $\mathrm{Mn} 2 \mathrm{p}_{3 / 2}(642.0 \mathrm{eV})$, which were characteristics of Mn(IV) [57]. As for Fe(III), the XPS peaks were $\mathrm{Fe} 2 \mathrm{p}_{1 / 2}(723.8 \mathrm{eV})$ and $\mathrm{Fe} 2 \mathrm{p}_{3 / 2}(710.2 \mathrm{eV})$ [58]. In addition, the energy difference between the $\mathrm{Fe} 2 \mathrm{p}_{3 / 2}$ and $\mathrm{Fe} 2 \mathrm{p}_{1 / 2}$ spin-orbit levels was approximately 13.6 eV (Fig. 6e), which was agreed with previous reports analyzing Fe(III) solids [59]. Meanwhile, a comparison of the shape and centroid before and after adsorption of Cd(II) implied that $\mathrm{Fe} 2 \mathrm{p}$ peaks were nearly as same as $\mathrm{BC}$, while $\mathrm{Mn} 2 \mathrm{p}_{3 / 2}$ peak was subjected to a change with the centroid shifted towards the lower-binding-energy side (Fig. 6d, e). This result revealed that the chemical state of Fe was not changed, whereas Mn(IV) was partly transformed to $\mathrm{Mn}(\mathrm{II})$ [60]. After adsorption, peaks of Cd 3d appeared (Fig. S5), confirming the capture of Cd(II) onto the adsorbent. Deconvolution of the Cd $3 \mathrm{~d}$ peaks (Fig. 6f) indicated that $\mathrm{Cd}(\mathrm{II})$ on $\mathrm{FMBC}$ presented in the form of $\mathrm{Cd}(\mathrm{OH})_{2}(63.9$ $\mathrm{wt} \%$ ) and $\mathrm{CdO}(36.1 \mathrm{wt} \%)$. Thereby, the precipitation and chelation of $\mathrm{Cd}(\mathrm{II})$ had 
influenced the adsorption process significantly. The $\mathrm{Cd}(\mathrm{II})-\pi$ bonding with the soft oxygenated functional groups such as $-\mathrm{C}=\mathrm{O}$ might become the predominant mode of $\mathrm{Cd}(\mathrm{II})$ adsorption [61]. In addition, $\mathrm{FMBC}$ has stronger electron-rich domains of $\mathrm{C}=\mathrm{C}$ than $\mathrm{BC}$. Thus, the $\mathrm{Cd}(\mathrm{II})-\pi$ interaction might have enhanced, and resulted in the higher adsorption of $\mathrm{Cd}(\mathrm{II})$ on the modified biochar [62]. In general, FMBC had a better $\mathrm{Cd}(\mathrm{II})$ adsorption ability than $\mathrm{BC}$ because both $\mathrm{MnO}_{\mathrm{x}}$ and oxygen-containing functional groups on FMBC exhibited a strong binding affinity to $\mathrm{Cd}(\mathrm{II})$ in aqueous solutions.

\section{Conclusions}

Through this study, we demonstrated successful fabrication of a designer biochar (FMBC) for $\mathrm{Cd}(\mathrm{II})$ removal from aqueous solutions by loading Fe-Mn binary oxide particles on a biochar (BC) derived from the straw of Pennisetum sp. The FMBC exhibited a rougher surface, larger SSA, and higher pore volume than $\mathrm{BC}$, and the maximum $\mathrm{Cd}(\mathrm{II})$ adsorption capacity of FMBC $(95.23 \mathrm{mg} / \mathrm{g})$ was approximately 3 times higher than that of $\mathrm{BC}(30.58 \mathrm{mg} / \mathrm{g})$. Enhanced $\mathrm{O}$ content, $\mathrm{MnO}_{\mathrm{x}}$ particles as well as the additional oxygen containing functional groups were introduced on the surface of FMBC, which contributed to remarkably higher adsorption efficiency of FMBC than BC. The predominant adsorption mechanism was $\mathrm{Cd}(\mathrm{II})$ precipitation with ferromanganese oxides accompanied with $\mathrm{Cd}(\mathrm{II})-\pi$ bonding via the soft oxygenated functional groups $(-\mathrm{C}=\mathrm{O})$, complexation (e.g., $\mathrm{COO}-\mathrm{Cd}$ and $\mathrm{Mn}-\mathrm{O}-\mathrm{Cd})$, and cation exchange (between $\mathrm{Cd}(\mathrm{II})$ and $\mathrm{Ca}(\mathrm{II}), \mathrm{K}(\mathrm{I})$ ). These results have provided a solid theoretical foundation for the practical application of designer biochar in removing $\mathrm{Cd}(\mathrm{II})$ from aqueous solutions. Based on the evidence of the adsorption mechanisms in this work, future studies could be focused on the quantitative contribution of various mechanisms of $\mathrm{Cd}(\mathrm{II})$ adsorption by Fe-Mn binary oxide-biochar, as well as its further application to the practical wastewater treatment, even extending to $\mathrm{Cd}(\mathrm{II})$ - 
contaminated soil remediation.

\section{Acknowledgments}

This work was financially supported by the National Key Research and Development Program of China (2018YFC1800304, 2018YFC1802803, 2017YFD0801302), the National Natural Science Foundation of China (21677041, 51908136, 21876027), the Science and Technology Project of Guangzhou City (2016201604030017), and the Natural Science and Technology Project of Guangdong Province, China (2017B020216002, 2017A030311019, 2016A030313697).

\section{References}

[1] Bandara, T., Franks, A., Xu, J., Bolan, N., Wang, H., Tang, C., Chemical and biological immobilization mechanisms of potentially toxic elements in biocharamended soils. Crit. Rev. Env. Sci. Tec. (2019)1-76, https://doi.org/10.1080/10643389.2019.1642832.

[2] Liu, S., Ali, S., Yang, R., Tao, J., Ren, B., A newly discovered Cdhyperaccumulator Lantana camara L. J. Hazard. Mater. 371(2019) 233-242, DOI: 10.1016/j.jhazmat.2019.03.016.

[3] Mohan, D., Pittman, C.U., Jr., Bricka, M., Smith, F., Yancey, B., Mohammad, J., Steele, P.H., Alexandre-Franco, M.F., Gomez-Serrano, V., Gong, H., Sorption of arsenic, cadmium, and lead by chars produced from fast pyrolysis of wood and bark during bio-oil production. J Colloid Interface Sci. 310 (2007) 57-73, DOI: 10.1016/j.jcis.2007.01.020. 
[4] Doke, S.M., Yadav, G.D., Process efficacy and novelty of titania membrane prepared by polymeric sol-gel method in removal of chromium(VI) by surfactant enhanced microfiltration. Chem. Eng. J. 255(2014) 483-491, DOI: 10.1016/j.cej.2014.05.098.

[5] Chakraborty, S., Dasgupta, J., Farooq, U., Sikder, J., Drioli, E., Curcio, S., Experimental analysis, modeling and optimization of chromium (VI) removal from aqueous solutions by polymer-enhanced ultrafiltration. J. Membrane. Sci. 456 (2014) 139-154, DOI: 10.1016/j.memsci.2014.01.016.

[6] Heidmann, I., Calmano, W., Removal of $\mathrm{Zn}(\mathrm{II}), \mathrm{Cu}(\mathrm{II}), \mathrm{Ni}(\mathrm{II}), \mathrm{Ag}(\mathrm{I})$ and $\mathrm{Cr}(\mathrm{VI})$ present in aqueous solutions by aluminium electrocoagulation. J. Hazard. Mater. 152(2008) 934-941, DOI: 10.1016/j.jhazmat.2007.07.068.

[7] Cavaco, S.A., Fernandes, S., Quina, M.M., Ferreira, L.M., Removal of chromium from electroplating industry effluents by ion exchange resins. J. Hazard. Mater. 144(2007) 634-638, DOI: 10.1016/j.jhazmat.2007.01.087.

[8] Won, S.W., Kotte, P., Wei, W., Lim, A., Yun, Y.S., Biosorbents for recovery of precious metals. Bioresour. Technol. 160(2014) 203-212, DOI: 10.1016/j.biortech.2014.01.121.

[9] Ahmad, Z., Gao, B., Mosa, A., Yu, H., Yin, X., Bashir, A., Ghoveisi, H., Wang, S., Removal of $\mathrm{Cu}(\mathrm{II}), \mathrm{Cd}(\mathrm{II})$ and $\mathrm{Pb}(\mathrm{II})$ ions from aqueous solutions by biochars derived from potassium-rich biomass. J. Clean. Prod. 180(2018) 437-449, DOI: 10.1016/j.jclepro.2018.01.133.

[10]Li, B., Yang, L., Wang, C.Q., Zhang, Q.P., Liu, Q.C., Li, Y.D., Xiao, R., Adsorption 
of $\mathrm{Cd}(\mathrm{II})$ from aqueous solutions by rape straw biochar derived from different modification processes. Chemosphere. 175(2017) 332-340, DOI: 10.1016/j.chemosphere.2017.02.061.

[11]Zhou, Y., Gao, B., Zimmerman, A.R., Chen, H., Zhang, M., Cao, X., Biocharsupported zerovalent iron for removal of various contaminants from aqueous solutions. Bioresour. Technol. 152(2014) 538-542, DOI: 10.1016/j.biortech.2013.11.021.

[12]Yang, X., Wan, Y., Zheng, Y., He, F., Yu, Z., Huang, J., Wang, H., Ok, Y.S., Jiang, Y., Gao, B., Surface functional groups of carbon-based adsorbents and their roles in the removal of heavy metals from aqueous solutions: A critical review. Chem. Eng. J. 366(2019) 608-621, DOI: 10.1016/j.cej.2019.02.119.

[13]Zama, E.F., Zhu, Y.-G., Reid, B.J., Sun, G.-X., The role of biochar properties in influencing the sorption and desorption of $\mathrm{Pb}(\mathrm{II}), \mathrm{Cd}(\mathrm{II})$ and $\mathrm{As}(\mathrm{III})$ in aqueous solution. J. Clean. Prod. 148(2017) 127-136, DOI: 10.1016/j.jclepro.2017.01.125.

[14]Cui, X., Dai, X., Khan, K.Y., Li, T., Yang, X., He, Z., Removal of phosphate from aqueous solution using magnesium-alginate/chitosan modified biochar microspheres derived from Thalia dealbata. Bioresour. Technol. 218(2016) 11231132, DOI: $10.1016 /$ j.biortech.2016.07.072.

[15]Yu, Z., Qiu, W., Wang, F., Lei, M., Wang, D., Song, Z., Effects of manganese oxidemodified biochar composites on arsenic speciation and accumulation in an indica rice (Oryza sativa L.) cultivar. Chemosphere. 168(2017) 341-349, DOI: 10.1016/j.chemosphere.2016.10.069. 
[16] Wang, H., Gao, B., Wang, S., Fang, J., Xue, Y., Yang, K., Removal of Pb(II), $\mathrm{Cu}(\mathrm{II})$, and $\mathrm{Cd}(\mathrm{II})$ from aqueous solutions by biochar derived from $\mathrm{KMnO}_{4}$ treated hickory wood. Bioresour. Technol. 197(2015a) 356-362, DOI: 10.1016/j.biortech.2015.08.132.

[17]Wu, P., Cui, P., Alves, M.E., Peijnenburg, W.J.G.M., Liu, C., Zhou, D., Wang, H., Ok, Y.S., Wang, Y., Interactive effects of rice straw biochar and $\gamma-\mathrm{Al}_{2} \mathrm{O}_{3}$ on immobilization of Zn. J. Hazard. Mater. 373(2019) 250-257, DOI:10.1016/j.jhazmat.2019.03.076.

[18]Jiang, L., Xiao, S., Chen, J., Removal behavior and mechanism of Co(II) on the surface of Fe-Mn binary oxide adsorbent. Colloid. Surface. A. 479(2015) 1-10. DOI: 10.1016/j.colsurfa.2015.03.05.

[19]Liu, R., Liu, F., Hu, C., He, Z., Liu, H., Qu, J., Simultaneous removal of Cd(II) and $\mathrm{Sb}(\mathrm{V})$ by Fe-Mn binary oxide: Positive effects of $\mathrm{Cd}(\mathrm{II})$ on $\mathrm{Sb}(\mathrm{V})$ adsorption. J. Hazard. Mater. 300(2015) 847-854, DOI: 10.1016/j.jhazmat.2015.08.020.

[20]Sarkar, S., Guibal, E., Quignard, F., SenGupta, A.K., Polymer-supported metals and metal oxide nanoparticles: synthesis, characterization, and applications. J. of Nanopart. Res. 14(2012) 715, DOI: 10.1007/s11051-011-0715-2.

[21]Khan, K., Factor-Litvak, P., Wasserman, G.A., Liu, X., Ahmed, E., Parvez, F., Slavkovich, V., Levy, D., Mey, J., van Geen, A., Graziano, J.H., Manganese exposure from drinking water and children's classroom behavior in Bangladesh. Environ. Health Persp. 119(2011) 1501-1506, DOI: 10.1289/ehp.1003397.

[22]Li, X., He, K., Pan, B., Zhang, S., Lu, L., Zhang, W., 2012. Efficient As(III) removal by macroporous anion exchanger-supported Fe-Mn binary oxide: Behavior and mechanism. Chem. Eng. J. 193(2012) 131-138, DOI: 
10.1016/j.cej.2012.04.036.

[23]Mandal, S., Sarkar, B., Mukhopadhyay, R., Biswas, J.K., Manjaiah, K.M., Microparticle-supported nanocomposites for safe environmental applications., Nanomaterials: Ecotoxicity, Safety, and Public Perception. Springer International Publishing, New York, 2018, pp. 305-317.

[24]Lin, L., Gao, M., Qiu, W., Wang, D., Huang, Q., Song, Z., 2017a. Reduced arsenic accumulation in indica rice (Oryza sativa L.) cultivar with ferromanganese oxide impregnated biochar composites amendments. Environ. Pollut. 231(2017a) 479486, DOI: 10.1016/j.envpol.2017.08.001.

[25]Lin, L., Qiu, W., Wang, D., Huang, Q., Song, Z., Chau, H.W., Arsenic removal in aqueous solution by a novel Fe-Mn modified biochar composite: Characterization and mechanism. Ecotoxicol. Environ. Saf. 144(2017b) 514-521, DOI: 10.1016/j.ecoenv.2017.06.063.

[26]Zhou, Q., Liao, B., Lin, L., Qiu, W., Song, Z., Adsorption of Cu(II) and Cd(II) from aqueous solutions by ferromanganese binary oxide-biochar composites. Sci. Total. Environ. 615(2018) 115-122, DOI: 10.1016/j.scitotenv.2017.09.220.

[27]Song, Z., Lian, F., Yu, Z., Zhu, L., Xing, B., Qiu, W., Synthesis and characterization of a novel MnOx-loaded biochar and its adsorption properties for $\mathrm{Cu}^{2+}$ in aqueous solution. Chem. Eng. J. 242(2014) 36-42, DOI: 10.1016/j.cej.2013.12.061.

[28]Brunauer, S., Emmett, P. H., Teller, E., Adsorption of gases in multimolecular layers. J. Am. Chem. Soc., 60(1938) 309-319, DOI: 10.1021/ja01269a023..

[29]Liu, L., Fan, S., Removal of cadimum in aqueous solution using wheat straw 
biochar: effect of minerals and mechanism. Environ. Sci. Pollut. R. 25(2018) 86888700, DOI:10.1007/s11356-017-1189-2.

[30]Lu, H., Zhang, W., Yang, Y., Huang, X.,Wang, S., Qiu, R., Relative distribution of $\mathrm{Pb}^{2+}$ sorption mechanisms by sludge-derived biochar. Water Res. 46(2012) 854862, DOI:10.1016/j.wateres.2011.11.058.

[31]Inyang, M., Gao, B., Zimmerman, A., Zhou, Y., Cao, X., Sorption and cosorption of lead and sulfapyridine on carbon nanotube-modified biochars. Environ. Sci. Pollut. R. 22(2014) 1868-1876, DOI: 10.1007/s11356-014-2740-z.

[32]Wang, S., Gao, B., Zimmerman, A.R., Li, Y., Ma, L., Harris, W.G., Migliaccio, K.W., Removal of arsenic by magnetic biochar prepared from pinewood and natural hematite. Bioresour. Technol. 175(2015c) 391-395, DOI: 10.1016/j.biortech.2014.10.104.

[33]Zeng, G., Liu, Y., Tang, L., Yang, G., Pang, Y., Zhang, Y., Zhou, Y., Li, Z., Li, M., Lai, M., He, X., He, Y., Enhancement of Cd(II) adsorption by polyacrylic acid modified magnetic mesoporous carbon. Chem. Eng. J. 259(2015) 153-160, DOI: 10.1016/j.cej.2014.07.115.

[34]Trakal, L., Šigut, R., Šillerová, H., Faturíková, D., Komárek, M., Copper removal from aqueous solution using biochar: Effect of chemical activation. Arab. J. Chem. 7(2014) 43-52, DOI: 10.1016/j.arabjc.2013.08.001.

[35]Liang, J., Li, X., Yu, Z., Zeng, G., Luo, Y., Jiang, L., Yang, Z., Qian, Y., Wu, H., Amorphous $\mathrm{MnO}_{2}$ modified biochar derived from aerobically composted swine manure for adsorption of $\mathrm{Pb}(\mathrm{II})$ and $\mathrm{Cd}(\mathrm{II})$. ACS Sustain. Chem. Eng. 5(2017) 
5049-5058,DOI: 10.1021/acssuschemeng.7b00434.

[36]Lin, L., Qiu, W. , Wang, D. , Huang, Q., Song, Z., Chau, HW. Arsenic removal in aqueous solution by a novel Fe-Mn modified biochar composite: Characterization and mechanism. Ecotox. Environ. Safe., 144(2017)514-521, DOI:10.1016/j.ecoenv.2017.06.063)

[37]Dawood, S., Sen, T.K., Removal of anionic dye Congo red from aqueous solution by raw pine and acid-treated pine cone powder as adsorbent: Equilibrium, thermodynamic, kinetics, mechanism and process design. Water Res. 46(2012) 1933-1946, DOI: 10.1016/j.watres.2012.01.009.

[38]Zou,X., Pan, J., Ou, H., Wang, X., Guan,W., Li, C., Yan,Y., Duan, Y., Adsorptive removal of $\mathrm{Cr}(\mathrm{III})$ and $\mathrm{Fe}(\mathrm{III})$ from aqueous solution by chitosan/attapulgite composites: equilibrium, thermodynamics and kinetics. Chem. Eng. J. 167(2011) 112-121,DOI: 10.1016/j.cej.2010.12.009.

[39]Qiu, Y., Zhang, Q., Li, M., Fan, Z., Sang, W., Xie, C., Niu, D., Adsorption of Cd(II) From aqueous solutions by modified biochars: comparison of modification methods. Water Air. Soil Poll. 230(2019)84, DOI: 10.1007/s11270-019-4135-8.

[40]Rusmin, R., Sarkar, B., Liu, Y., McClure, S., Naidu, R., Structural evolution of chitosan-palygorskite composites and removal of aqueous lead by composite beads. Appl. Surf. Sci. 353(2015) 363-375, DOI: 10.1016/j.apsusc.2015.06.124.

[41]Liang, J., Liu, J., Yuan, X., Dong, H., Zeng, G., Wu, H., Wang, H., Liu, J., Hua, S., Zhang, S., Yu, Z., He, X., He, Y., Facile synthesis of alumina-decorated multi- 
walled carbon nanotubes for simultaneous adsorption of cadmium ion and trichloroethylene. Chem. Eng. J. 273(2015) 101-110, DOI: 10.1016/j.cej.2015.03.069.

[42]Ahmad, M., Rajapaksha, A.U., Lim, J.E., Zhang, M., Bolan, N., Mohan, D., Vithanage, M., Lee, S.S., Ok, Y.S., Biochar as a sorbent for contaminant management in soil and water: a review. Chemosphere. 99(2014) 19-33, DOI: 10.1016/j.chemosphere.2013.10.071.

[43]Mohan, D., Sarswat, A., Ok, Y.S., Pittman, C.U., Jr., Organic and inorganic contaminants removal from water with biochar, a renewable, low cost and sustainable adsorbent-- a critical review. Bioresour. Technol. 160(2014) 191-202, DOI: 10.1016/j.biortech.2014.01.120.

[44]Wang, L., Wan, C., Lee, D.-J., Liu, X., Zhang, Y., Chen, X.F., Tay, J.-H., Biosorption of antimony(V) onto Fe(III)-treated aerobic granules. Bioresour. Technol. 158(2014) 351-354, DOI: 10.1016/j.biortech.2014.02.046.

[45] Tran, H.N., You,S., Ahamad, H., Chao, H., Mistakes and inconssitencies regarding adsorption of contaminants from aqueous solutions: A critical reviews. Water Res.120(2017) 88-116, DOI:10.1016/j.waters.2017.04.014.

[46]Jefferson, W.A., Hu, C., Liu, H., Qu, J., Reaction of aqueous Cu-Citrate with $\mathrm{MnO}_{2}$ birnessite: characterization of Mn dissolution, oxidation products and surface interactions. $\quad$ Chemosphere. 119(2015) 1-7, DOI: 10.1016/j.chemosphere.2014.04.039.

[47]Qu, J., Meng, X., Jiang, X., You, H., Wang, P., Ye, X., Enhanced removal of Cd(II) 
from water using sulfur-functionalized rice husk: Characterization, adsorptive performance and mechanism exploration. J. Clean. Prod. 183(2018) 880-886, DOI: 10.1016/j.jclepro.2018.02.208.

[48]Wei, J., Tu, C., Yuan, G., Bi, D., Xiao, L., Theng, B.K.G., Wang, H., Ok, Y.S., Carbon-coated montmorillonite nanocomposite for the removal of chromium(VI) from aqueous solutions. J. Hazard. Mater. 368(2019) 541-549, DOI: 10.1016/j.jhazmat.2019.01.080.

[49]Zhang, H., Shao, J., Zhang, S., Zhang, X., Chen, H., Effect of phosphorus-modified biochars on immobilization of $\mathrm{Cu}$ (II), Cd (II), and As (V) in paddy soil. J. Hazard. Mater., 2019, DOI: 10.1016/j.jhazmat.2019.121349.

[50]Zhang, X., Lv, L., Qin, Y., Xu, M., Jia, X., Chen, Z. 2018. Removal of aqueous $\mathrm{Cr}(\mathrm{VI})$ by a magnetic biochar derived from Melia azedarach wood. Bioresource Technol., 256(2018) 1-10,DOI:10.1016/j.biortech.2018.01.145.

[51]Jiang, J., Xu, R.K., Jiang, T.Y., Li, Z., Immobilization of $\mathrm{Cu}(\mathrm{II}), \mathrm{Pb}(\mathrm{II})$ and $\mathrm{Cd}(\mathrm{II})$ by the addition of rice straw derived biochar to a simulated polluted Ultisol. J. Hazard. $\quad$ 229-230(2012) 145-150, https://doi.org/10.1016/j.jhazmat.2012.05.086.

[52]Wang, R.Z., Huang, D.L., Liu, Y.G., Zhang, C., Lai, C., Zeng, G.M., Cheng, M., Gong, X.M., Wan, J., Luo, H., Investigating the adsorption behavior and the relative distribution of $\mathrm{Cd}^{2+}$ sorption mechanisms on biochars by different feedstock. Bioresour. Technol. 261(2018) 265-271, DOI: 10.1016/j.biortech.2018.04.032. 
[53]Gao, L. Y., Deng, J. H., Huang, G. F., Li, K., Cai, K. Z., Liu, Y., Huang, F., Relative distribution of $\mathrm{Cd}^{2+}$ adsorption mechanisms on biochars derived from rice straw and sewage sludge. Bioresour. Technol. 272(2019) 114-122, DOI: 10.1016/j.biortech.2018.09.138.

[54]Xia, Y. X., Meng, L.Y., Jiang, Y.J., Zhang, Y.S., Dai, X.X., Zhao, M.J., Facile preparation of $\mathrm{MnO}_{2}$ functionalized baker's yeast composites and their adsorption mechanism for Cadmium. Chem. Eng. J. 259(2015) 927-935, DOI: 10.1016/j.cej.2014.08.071.

[55]Okpalugo, T.I.T., Papakonstantinou, P., Murphy, H., McLaughlin, J., Brown, N.M.D., High resolution XPS characterization of chemical functionalised MWCNTs and SWCNTs. Carbon. 43(2005) 153-161, DOI: 10.1016/j.carbon.2004.08.033.

[56]Wang, S., Gao, B., Li, Y., Mosa, A., Zimmerman, A.R., Ma, L.Q., Harris, W.G., Migliaccio, K.W., Manganese oxide-modified biochars: preparation, characterization, and sorption of arsenate and lead. Bioresour. Technol. 181(2015b) 13-17, DOI: 10.1016/j.biortech.2015.01.044.

[57]Zhang, G., Qu, J., Liu, H., Liu, R., Wu, R., Preparation and evaluation of a novel Fe-Mn binary oxide adsorbent for effective arsenite removal. Water Res. 41(2007) 1921-1928, DOI: 10.1016/j.watres.2007.02.009.

[58]Mao, Q., Zhou, Y., Yang, Y., Zhang, J., Liang, L., Wang, H., Luo, S., Luo, L., Jeyakumar, P., Ok, Y.S., Rizwan, M., Experimental and theoretical aspects of biochar-supported nanoscale zero-valent iron activating $\mathrm{H}_{2} \mathrm{O}_{2}$ for ciprofloxacin 
removal from aqueous solution. J. Hazard. Mater. 380(2019), DOI:10.1016/j.jhazmat.2019.120848

[59]Quan, H., Cheng, B., Xiao, Y., Lei, S., One-pot synthesis of $\alpha-\mathrm{Fe}_{2} \mathrm{O}_{3}$ nanoplatesreduced graphene oxide composites for supercapacitor application. Chem. Eng. J. 286(2016) 165-173, https://doi.org/10.1016/j.cej.2015.10.068.

[60]Shan, C., Tong, M., Efficient removal of trace arsenite through oxidation and adsorption by magnetic nanoparticles modified with Fe-Mn binary oxide. Water Res. 47(2013) 3411-3421, DOI: 10.1016/j.watres.2013.03.035.

[61]Harvey, O.R., Herbert, B.E., Rhue, R.D., Kuo, L.J., Metal interactions at the biochar-water interface: energetics and structure-sorption relationships elucidated by flow adsorption microcalorimetry. Environ. Sci. Technol. 45(2011) 5550-5556, DOI: $10.1021 / \mathrm{es} 104401 \mathrm{~h}$.

[62]Peng, H.B., Gao, P., Chu, G., Pan, B., Peng, J.H., Xing, B.S, Enhanced adsorption of $\mathrm{Cu}(\mathrm{II})$ and $\mathrm{Cd}(\mathrm{II})$ by phosphoric acid-modified biochars. Environ. Pollut. 229(2017)846-853, DOI: 10.1016/j.envpol.2017.07.004. 
Table 1

Main properties of pristine biochar (BC) and ferromanganese binary oxide-BC composite (FMBC).

\begin{tabular}{|c|c|c|c|c|c|c|c|c|c|c|c|}
\hline Adsorbents & $\begin{array}{c}\text { SSA } \\
\left(\mathrm{m}^{2} / \mathrm{g}\right)\end{array}$ & $\begin{array}{c}\text { Total pore } \\
\text { volume } \\
\left(\mathrm{cm}^{3} / \mathrm{g}\right)\end{array}$ & $\begin{array}{c}\text { Average } \\
\text { pore size } \\
(\mathrm{nm})\end{array}$ & $\mathrm{pH}$ & $\mathrm{CEC}$ & $\mathrm{C}(\%)$ & $\mathrm{H}(\%)$ & $\mathrm{N}(\%)$ & $\mathrm{S}(\%)$ & $\mathrm{H} / \mathrm{C}$ & $\mathrm{C} / \mathrm{N}$ \\
\hline $\mathrm{BC}$ & 2.5137 & 0.0058 & 44.7132 & 9.5 & 27.95 & 73.79 & 2.93 & 0.86 & 0.28 & 0.47 & 100.10 \\
\hline FMBC & 8.8030 & 0.0205 & 9.6667 & 10.1 & 44.50 & 46.96 & 2.43 & 0.91 & 0.20 & 0.62 & 60.20 \\
\hline
\end{tabular}

Table 2

$\mathrm{Cd}(\mathrm{II})$ adsorption isotherm parameters fitted with Langmuir and Freundlich models.

\begin{tabular}{|c|c|c|c|c|c|c|c|c|c|c|c|c|}
\hline \multirow[b]{2}{*}{ Adsorbents } & \multicolumn{6}{|c|}{ Langmuir model } & \multicolumn{6}{|c|}{ Freundlich model } \\
\hline & $\begin{array}{c}\mathrm{K}_{\mathrm{L}} \\
(\mathrm{L} / \mathrm{mg})\end{array}$ & $\begin{array}{c}\mathrm{Q}_{\mathrm{m}} \\
(\mathrm{mg} / \mathrm{g})\end{array}$ & $\mathrm{R}^{2}$ & $\mathrm{R}^{2}{ }_{\text {adj }}$ & RMSE & RPD & $1 / \mathrm{n}$ & $\begin{array}{c}\mathrm{K}_{\mathrm{F}} \\
((\mathrm{mg} / \mathrm{g}) \\
\left.(\mathrm{L} / \mathrm{mg})^{1 / \mathrm{n}}\right)\end{array}$ & $\mathrm{R}^{2}$ & $\mathrm{R}^{2}{ }_{\text {adj }}$ & RMSE & RPD \\
\hline $\mathrm{BC}$ & 0.0234 & 30.5810 & 0.9985 & 0.9999 & 0.0580 & 3.4643 & 0.3913 & 3.4736 & 0.9939 & 0.9854 & 0.0304 & 0.9613 \\
\hline FMBC & 3.5000 & 95.2381 & 0.9999 & 0.9965 & 0.0034 & 3.4639 & 0.1095 & 62.3336 & 0.8992 & 0.8970 & 0.0800 & 0.9608 \\
\hline
\end{tabular}


Table 3

Kinetic model fitting parameters of Cd(II) adsorption by different adsorbents.

\begin{tabular}{|c|c|c|c|c|c|c|c|c|c|c|c|c|}
\hline \multirow[b]{2}{*}{ Adsorbents } & \multicolumn{6}{|c|}{ Pseudo first-order } & \multicolumn{6}{|c|}{ Pseudo second-order } \\
\hline & $\begin{array}{c}\mathrm{Q}_{\mathrm{e}} \\
(\mathrm{mg} / \mathrm{g})\end{array}$ & $\begin{array}{c}\mathrm{K}_{1} \\
(\mathrm{~g} /(\mathrm{mg} \cdot \min ))\end{array}$ & $\mathrm{R}^{2}$ & $\mathrm{R}^{2}$ adj & RMSE & RPD & $\begin{array}{c}\mathrm{Q}_{\mathrm{e}} \\
(\mathrm{mg} / \mathrm{g})\end{array}$ & $\begin{array}{c}\mathrm{K}_{2} \\
(\mathrm{~g} /(\mathrm{mg} \cdot \min ))\end{array}$ & $\mathrm{R}^{2}$ & $\mathrm{R}_{\text {adj }}^{2}$ & RMSE & RPD \\
\hline $\mathrm{BC}$ & 12.4571 & 0.9097 & 0.4620 & 0.5131 & 1.6000 & 0.9760 & 13.6110 & 0.0325 & 0.9996 & 0.9990 & 0.2634 & 42.7160 \\
\hline FMBC & 70.8421 & 2.8919 & 0.3284 & 0.2930 & 1.4000 & 0.9759 & 72.9927 & 0.0085 & 0.9999 & 0.9999 & 0.0488 & 642.69 \\
\hline
\end{tabular}

Table 4

Intraparticle diffusion model fitting parameters of $\mathrm{Cd}(\mathrm{II})$ adsorption by different adsorbents.

\begin{tabular}{|c|c|c|c|c|}
\hline \multirow{2}{*}{ Adsorbents } & \multicolumn{4}{|c|}{ Intraparticle diffusion } \\
\hline & $\mathrm{K}_{\mathrm{i}, 1}\left(\mathrm{mg} / \mathrm{g} / \mathrm{min}^{1 / 2}\right)$ & $\mathrm{R}_{\text {adj }}^{2}$ & $\mathrm{~K}_{\mathrm{i}, 2}\left(\mathrm{mg} / \mathrm{g} / \mathrm{min}^{1 / 2}\right)$ & $\mathrm{R}_{\text {adj }}^{2}$ \\
\hline $\mathrm{BC}$ & 0.9571 & 0.9905 & 0.0562 & 0.7737 \\
\hline FMBC & 0.8460 & 0.9659 & 0.0761 & 0.9024 \\
\hline
\end{tabular}




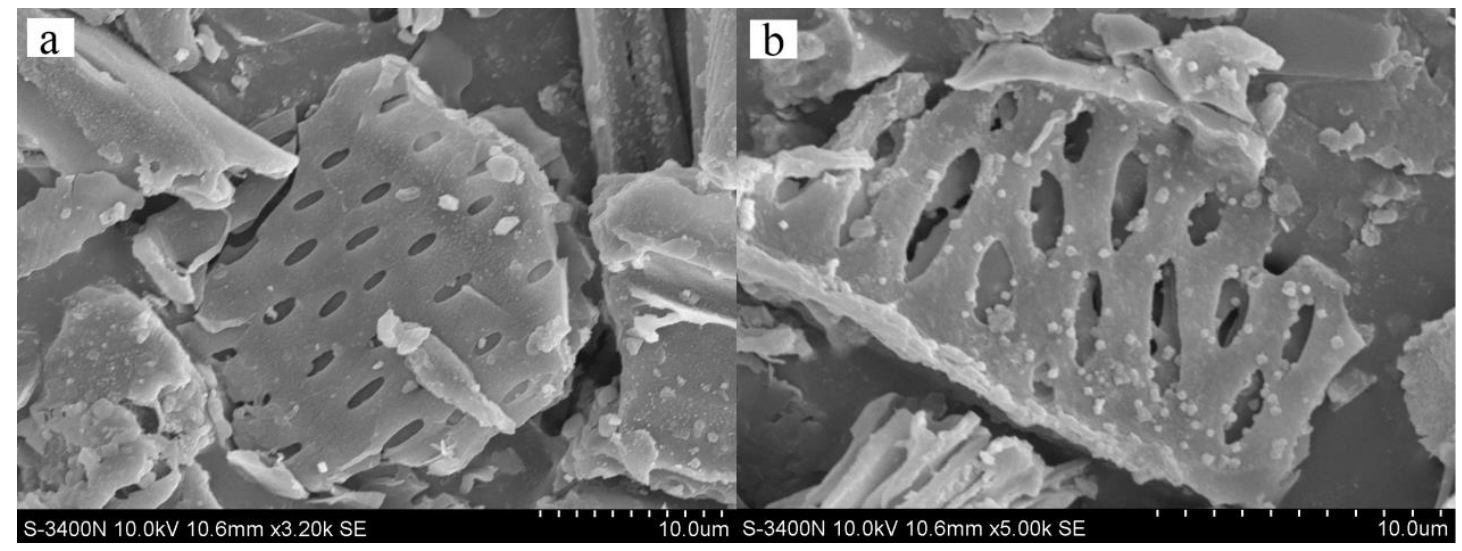

Fig. 1. SEM images of (a) pristine biochar (BC); and (b) ferromanganese binary oxide-BC composite (FMBC).
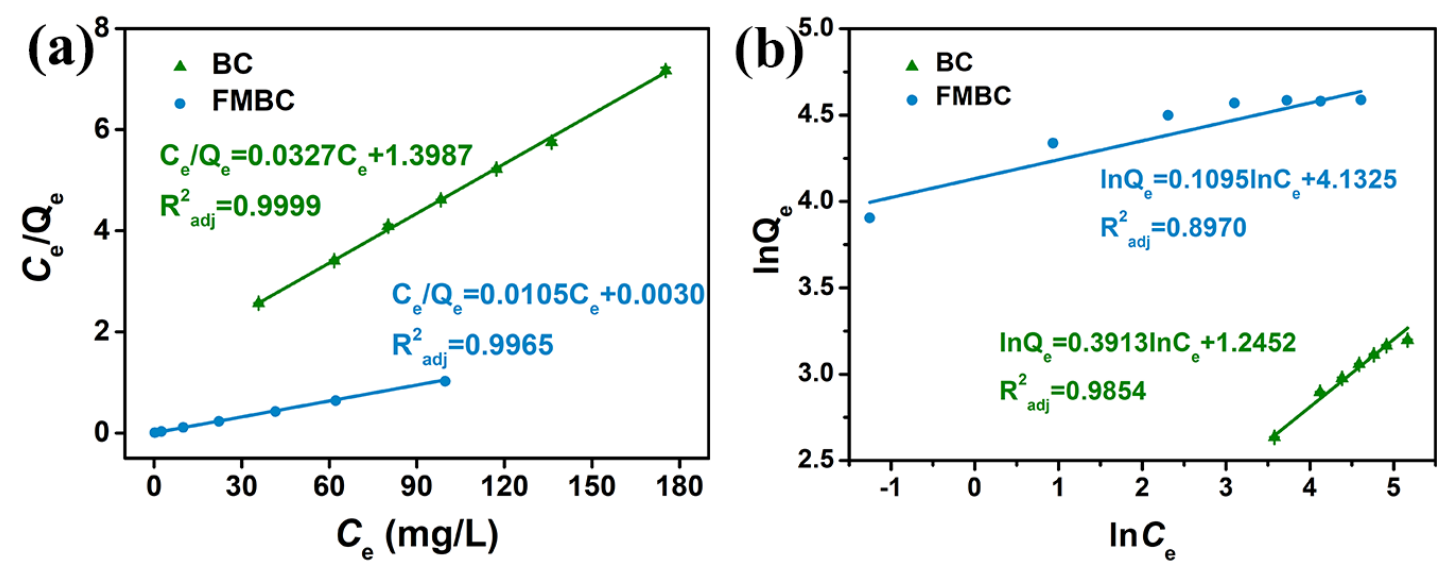

Fig. 2. Cd(II) adsorption isotherms fitted with (a) Langmuir model, and (b) Freundlich model.

$\mathrm{BC}$ : the pristine biochar; FMBC: ferromanganese binary oxide-BC composite. 

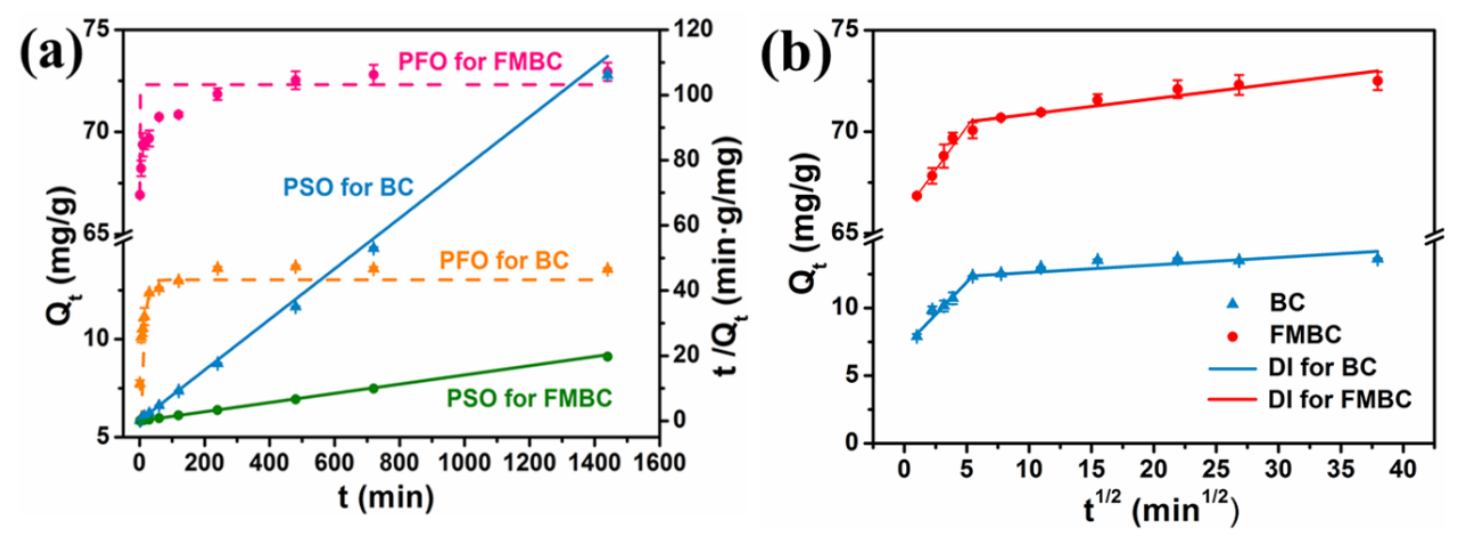

Fig. 3. Cd(II) adsorption kinetics fitted with (a) pseudo first order (PFO) and pseudo second order (PSO) models, and (b) intra-particle diffusion model. Initial Cd(II) concentration: $100 \mathrm{mg} / \mathrm{L}$.

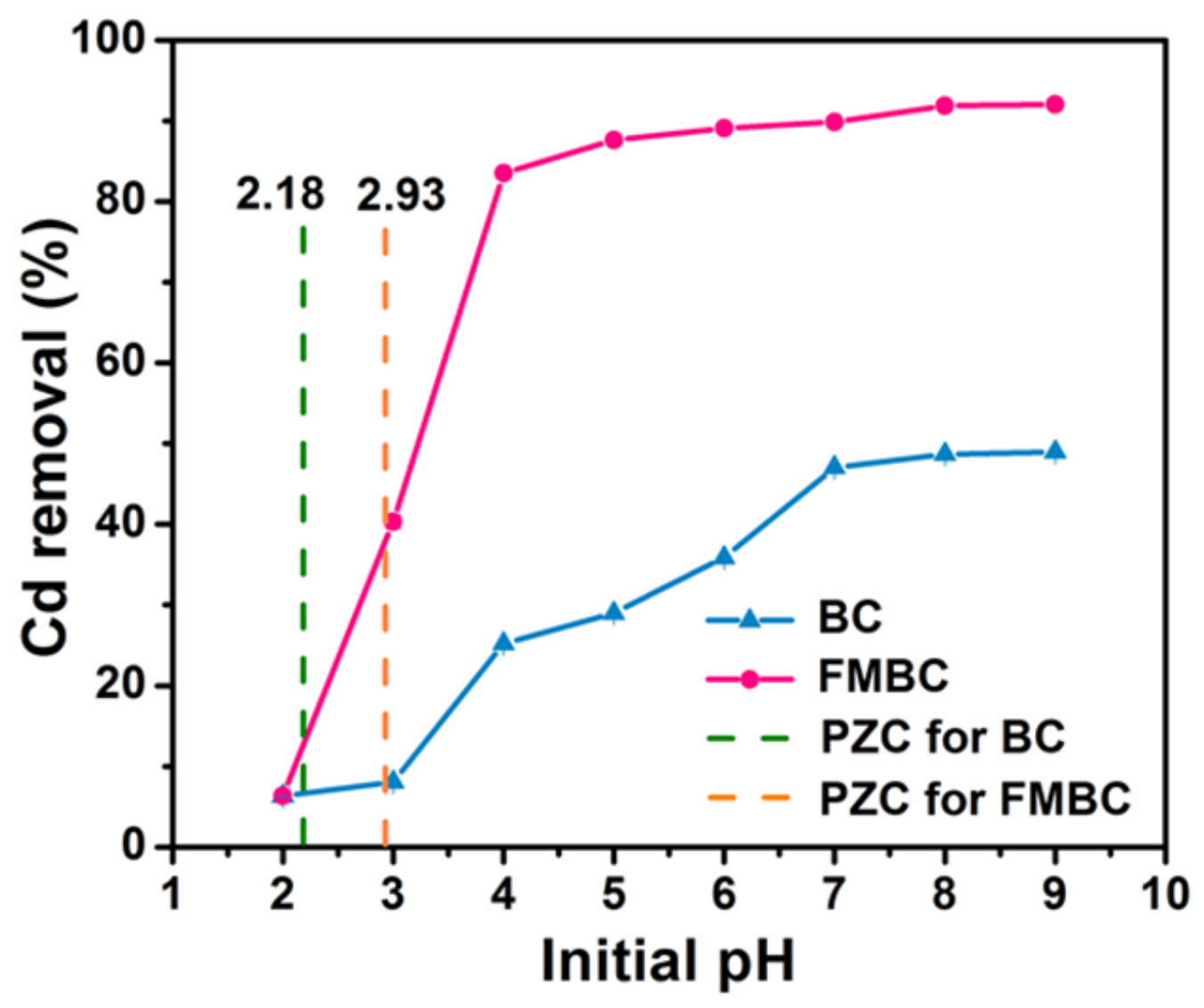

Fig. 4. Effect of $\mathrm{pH}$ on the adsorption of $\mathrm{Cd}(\mathrm{II})$ by the pristine biochar (BC) and ferromanganese binary oxide-BC composite (FMBC). 


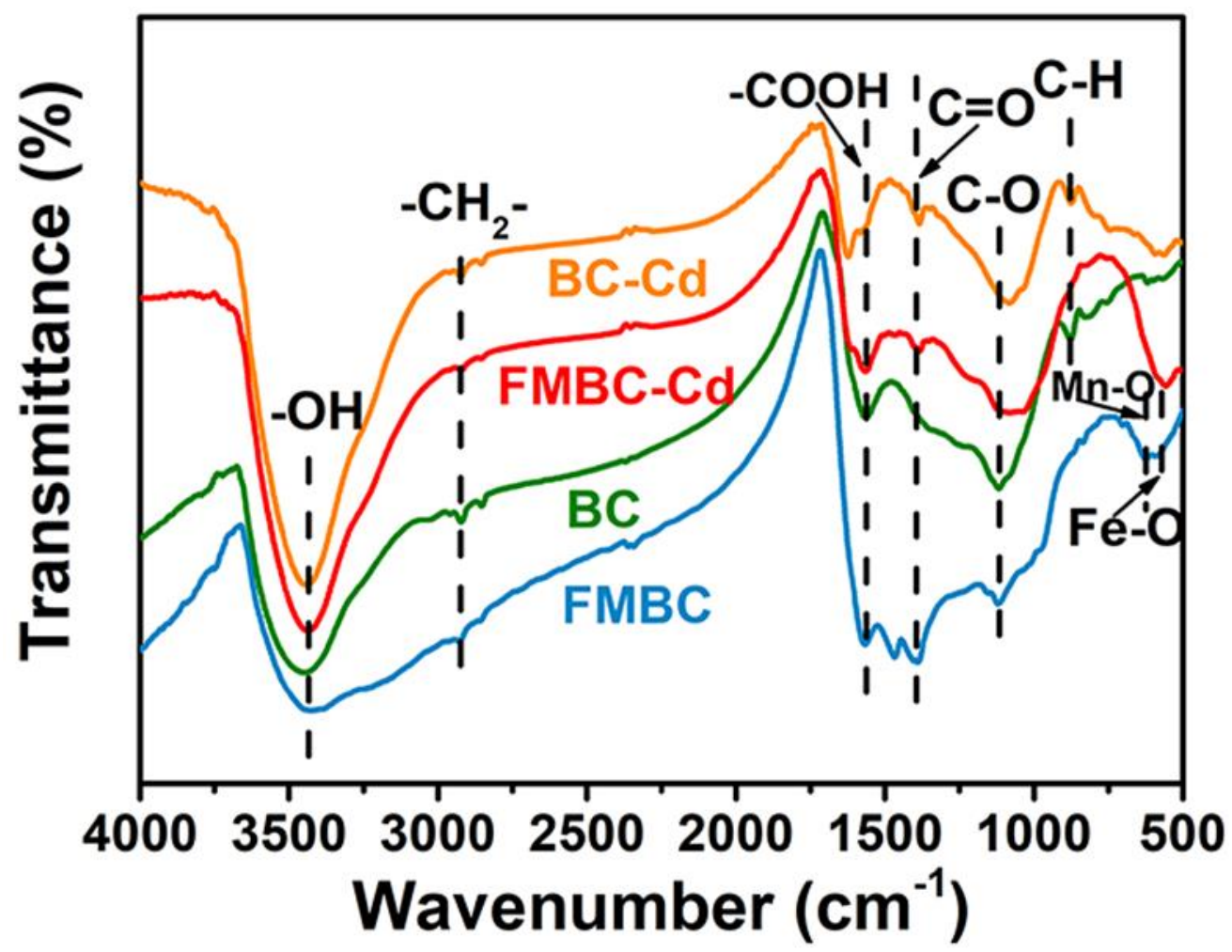

Fig. 5. FTIR spectra of the pristine biochar (BC) and ferromanganese binary oxideBC composite (FMBC) before and after $\mathrm{Cd}(\mathrm{II})$ adsorption. 

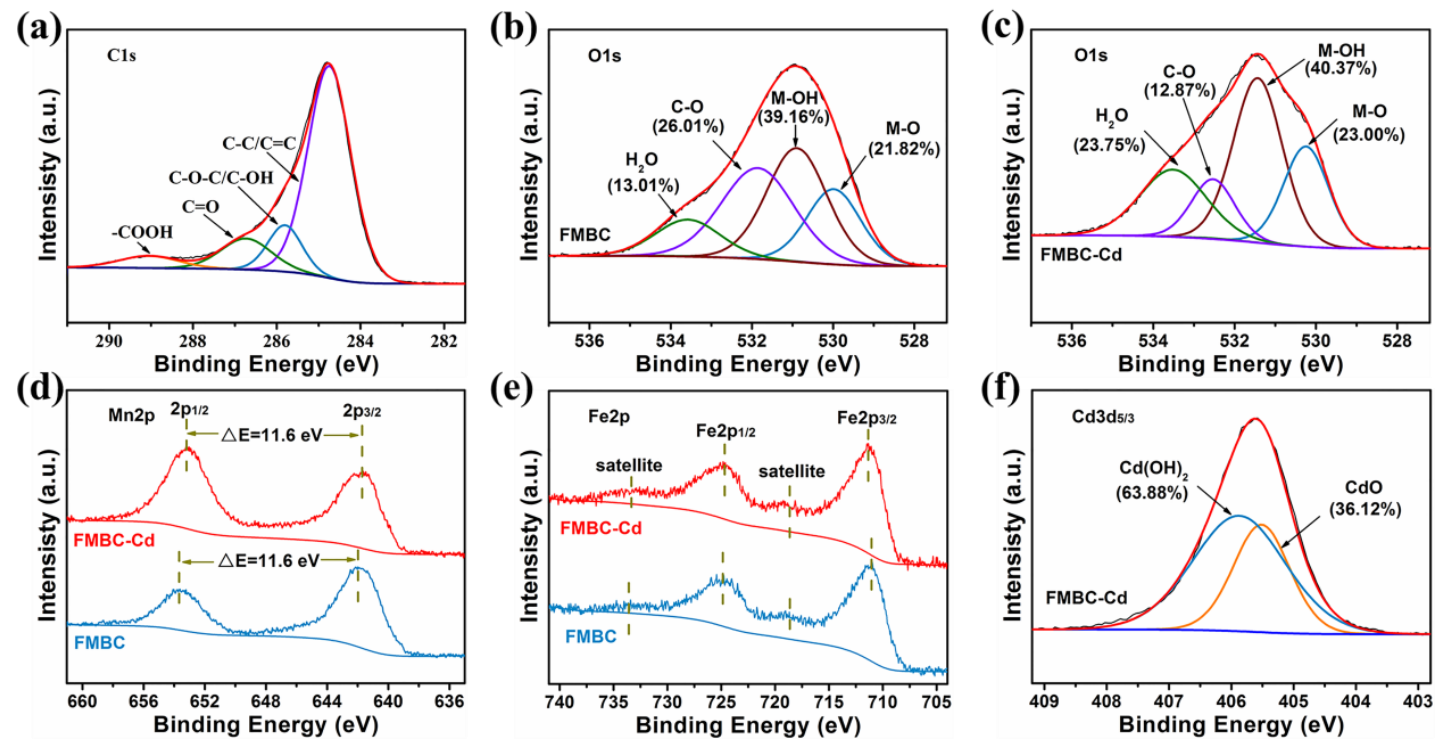

Fig. 6. XPS spectra of BC and FMBC before and after adsorption for Cd(II): (a) C 1s,

(b) O 1s for FMBC, (c) O 1s for FMBC-Cd(II), (d) Mn 2p, (e) Fe 2p, and (f) Cd 3d regions. 


\section{Supplementary Information for:}

\section{Novel Fe-Mn binary oxide-biochar as an adsorbent for removing $\mathrm{Cd}$ (II) from aqueous solutions}

Guangcai Yin ${ }^{\mathrm{a}}$, Xiaowang Song ${ }^{\mathrm{a}}$, Lin Tao ${ }^{\mathrm{a}}$, Binoy Sarkar ${ }^{\mathrm{b}}$, Ajit K Sarmah ${ }^{\mathrm{c}}$, Wenxiang Zhang $^{\text {a }}$, Qintie Lin ${ }^{\mathrm{a}}$, Rongbo Xiao ${ }^{\mathrm{a}}$, Qianjun Liu ${ }^{\mathrm{a}}$, Hailong Wang ${ }^{\mathrm{d}, \mathrm{e},}{ }^{*}$.

${ }^{a}$ School of Environmental Science and Engineering, Guangdong University of Technology, Guangzhou 510006, China

${ }^{b}$ Lancaster Environment Centre, Lancaster University, Lancaster, LA1 4YQ, UK

${ }^{c}$ Department of Civil and Environmental Engineering, The Faculty of Engineering, The University of Auckland, Private Bag 92010, Auckland 1142, New Zealand

${ }^{d}$ Key Laboratory of Soil Contamination Bioremediation of Zhejiang Province, Zhejiang A \&F University, Hangzhou 311300, China

${ }^{e}$ Biochar Engineering Technology Research Center of Guangdong Province, School of Environmental and Chemical Engineering, Foshan University, Foshan 528000, China

${ }^{*}$ Corresponding author.

E-mail address: hailong.wang@fosu.edu.cn (H. Wang). 


\section{Table S1}

Atomic percentage of elements on FMBC before and after adsorption of Cd(II).

\begin{tabular}{cccccccc}
\hline Material & $\mathrm{C}(\%)$ & $\mathrm{O}(\%)$ & $\mathrm{Cl}(\%)$ & $\mathrm{K}(\%)$ & $\mathrm{Fe}(\%)$ & $\mathrm{Mn}(\%)$ & $\mathrm{Cd}(\%)$ \\
\hline FMBC & 72.296 & 18.081 & 1.519 & 5.910 & 0.925 & 1.270 & 0.000 \\
$\begin{array}{c}\text { FMBC- } \\
\text { Cd }\end{array}$ & 58.757 & 23.658 & 0.000 & 0.406 & 0.787 & 1.134 & 15.258 \\
\hline
\end{tabular}

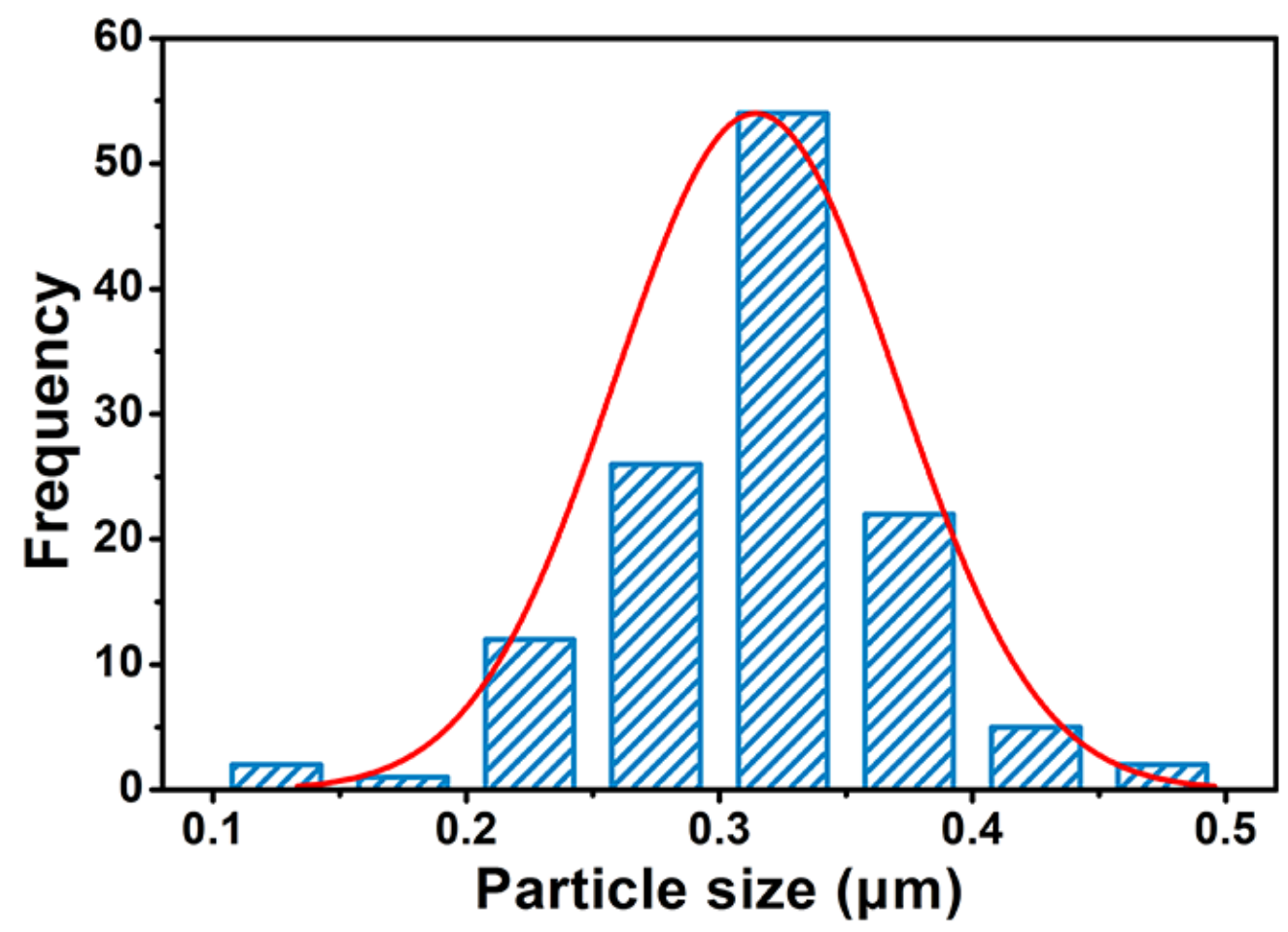

Fig. S1. Size of Fe-Mn binary oxide particles on the surface of FMBC. 


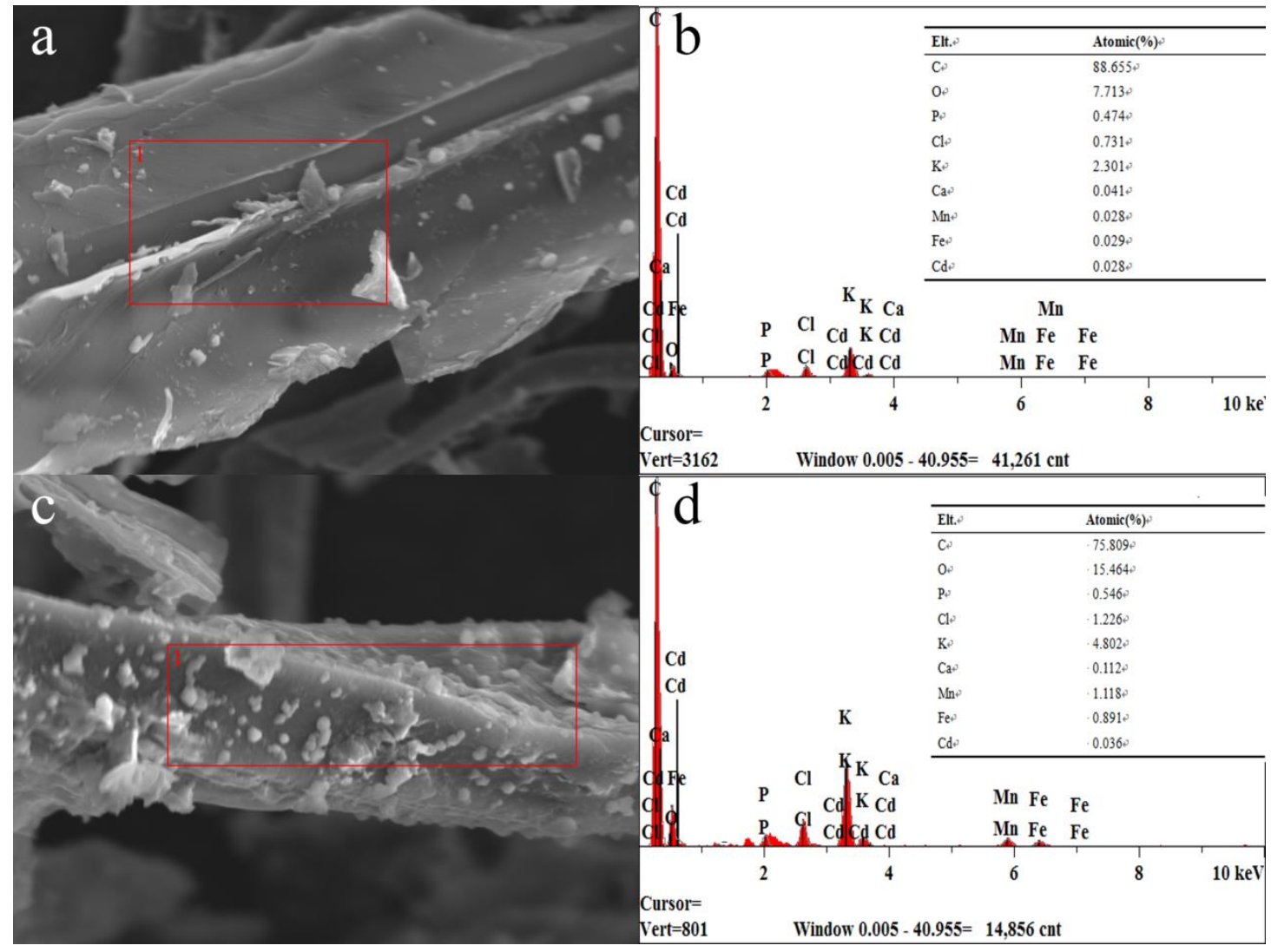

Fig. S2. Scanning electron micrographs and EDX spectra of BC $(a, b)$ and FMBC (c, d). 


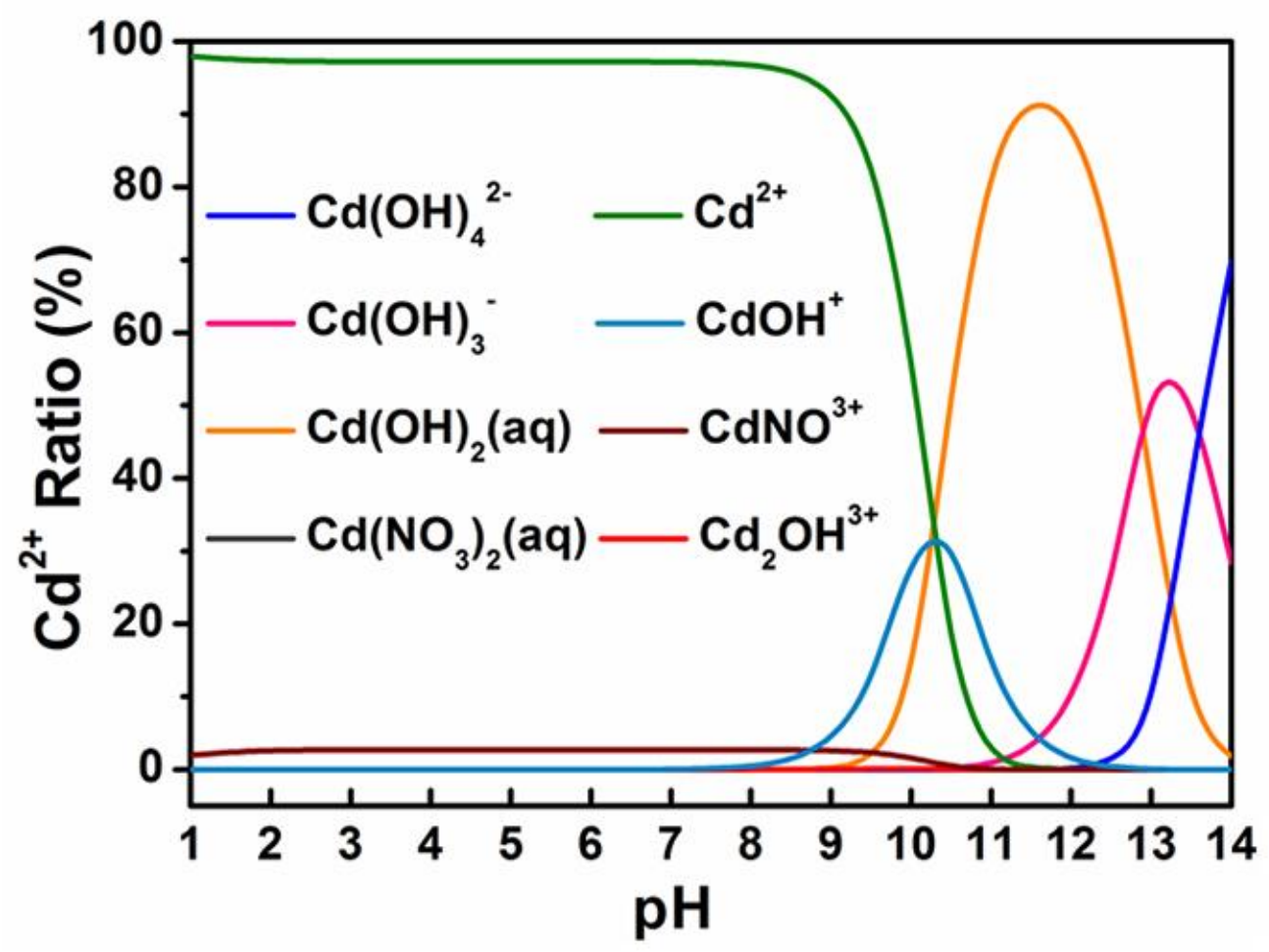

Fig. S3. Effect of $\mathrm{pH}$ on $\mathrm{Cd}$ speciation. Initial feed concentration of $\mathrm{Cd}^{2+}=100 \mathrm{mg} / \mathrm{L}$. 


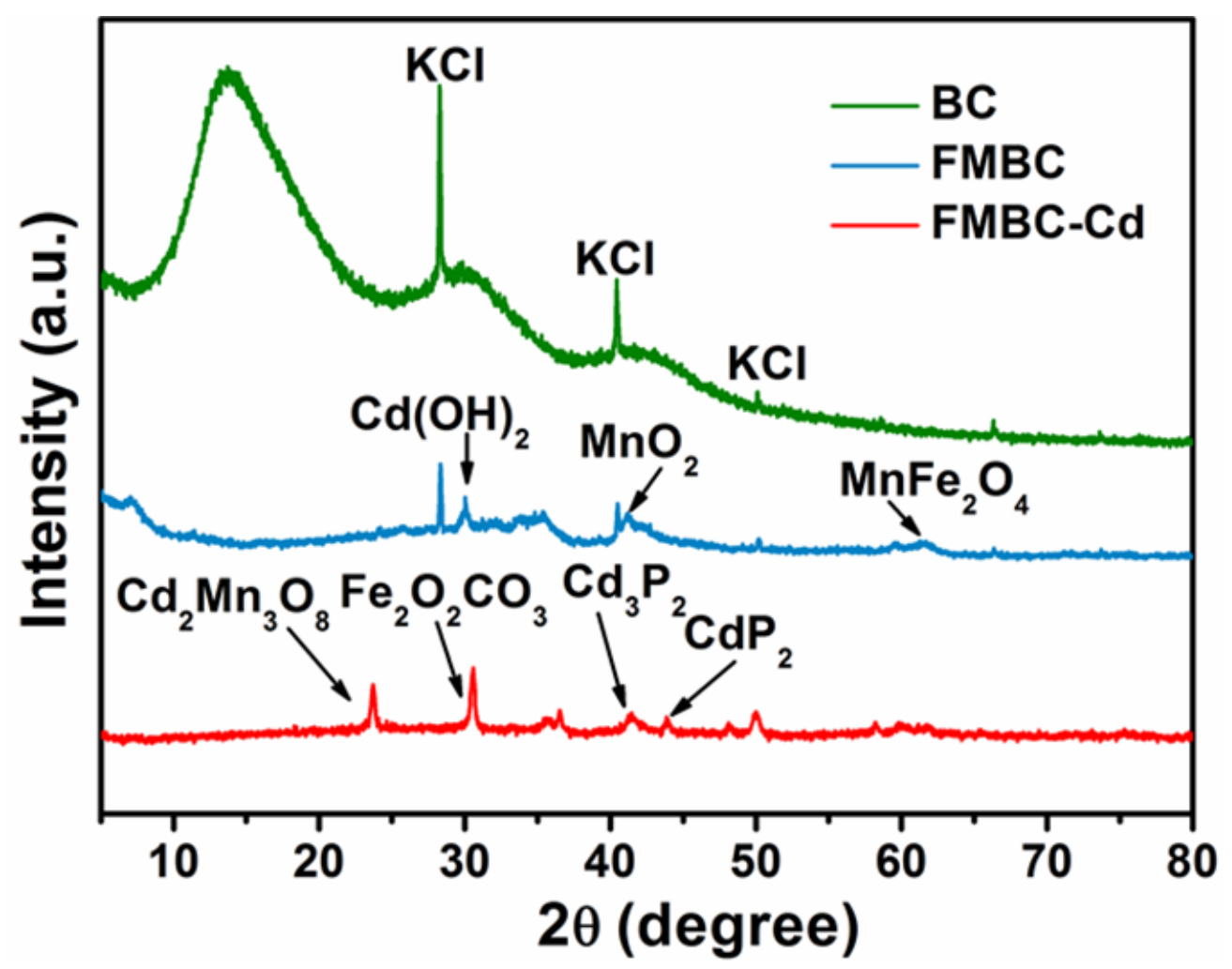

Fig. S4. XRD patterns of BC and FMBC before and after adsorption of $\mathrm{Cd}(\mathrm{II})$. 


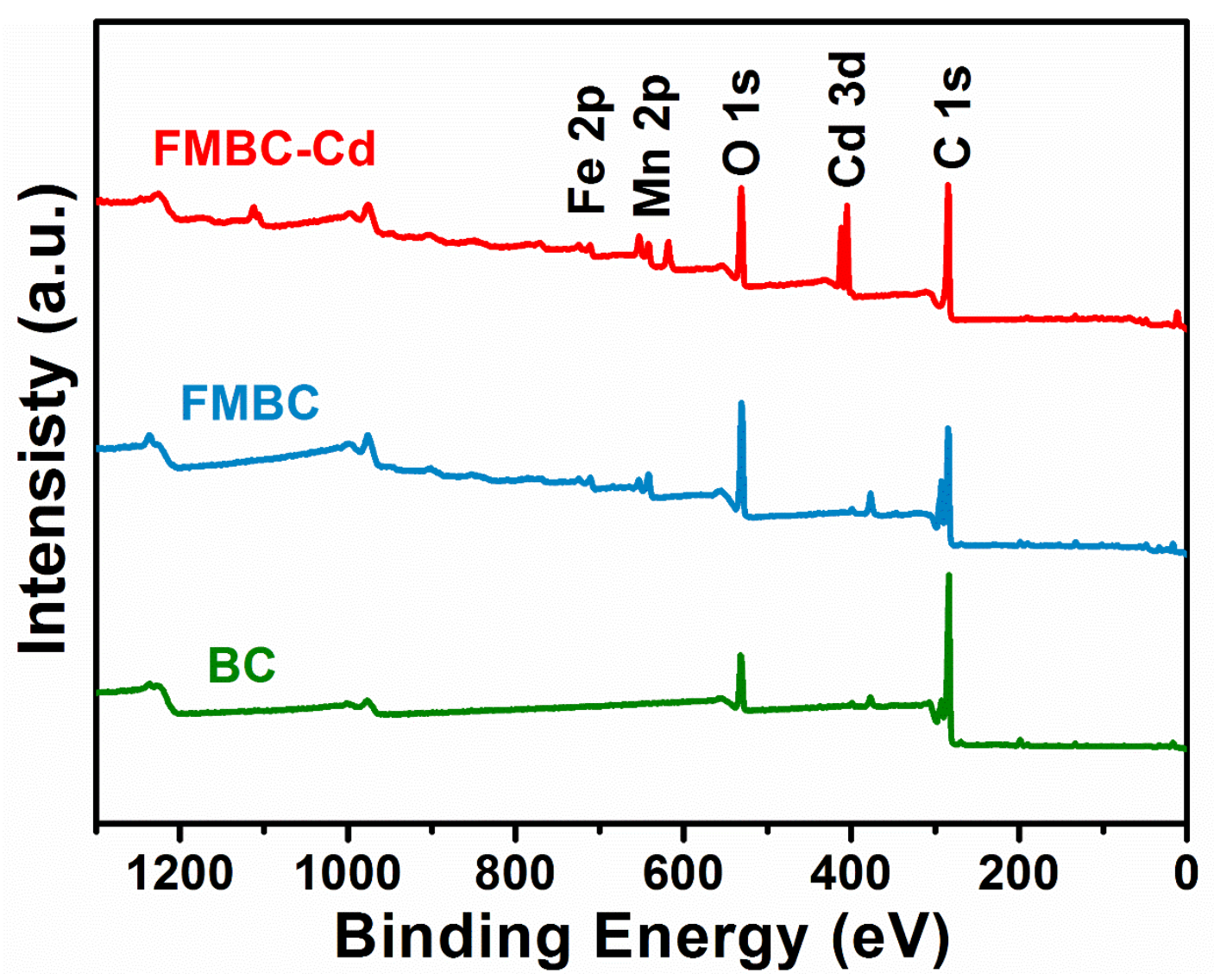

Fig. S5. XPS spectra of BC and FMBC before and after adsorption for Cd(II): wide scan 